Review Article

\title{
Factors Affecting and Optimization Methods used in Machining Duplex Stainless Steel - A Critical Review
}

\author{
Mahesh Gopal ${ }^{*}$ and Endalkachew Mosisa Gutema \\ Department of Mechanical Engineering, College of Engineering and Technology, Wollega University, Post Box No: 395, Nekemte, \\ Ethiopia.
}

Received 19 February 2021; Accepted 24 April 2021

\begin{abstract}
Due to exclusive universal value and usefulness, the combination of good mechanical properties and manufacturing characteristics, Stainless steel is an indispensable tool for design engineers to design components. In oil and gas companies, power plants such as nuclear and thermal, equipment's used in chemical processing industries: such as heat exchangers, seawater processing industries, Pipeline systems, face an incredible and exceptional challenge and the most important one is the reduction of thickness due to corrosion. In order to overcome this complexity, researchers developed a metal called duplex stainless steel (DSS). DSS is a mixture of Chromium - Nickel - Molybdenum - Ferric alloys that consists of an equal quantity of Face Centred Cubic (FCC) - austenite and Body Centred Cubic (BCC) - ferrite grains. DSS is designed to provide improved corrosion resistance, primarily stress corrosion and chloride pitting corrosion and superior resistance to other standard austenitic stainless steels. The DSS material is very difficult to perform machining operations due to high austenite, nitrogen content, alloy composition, high strength, work hardening rate and toughness. High hardness requires high cutting force which tends to reduce machinability characteristics such as tool wear, surface finish, low MRR, etc. This review article provides an overview of the research conducted during last one decade by the researchers and the optimization methods used to examine the machinability characteristics of DSS to predict surface unevenness wear in tool, machinability, MRR and chip volume ratio. Furthermore, this article indicates an efficient means of machining behavior, future scope and the fruitful methodology for the successful machining of duplex stainless steel.
\end{abstract}

Keywords: Duplex stainless steel, Austenite, Ferrite, Lean DSS, Standard DSS, Super DSS, Hyper DSS, Surface roughness, wear in Tool, Machinability, Material removal rate (MRR), Chip volume ratio.

\section{Introduction}

Machinability relates to how easily a metal may be machined to achieve a satisfactory surface finish., requires less energy to cut, can cut faster and less wear of the tools. Machinability is challenging to forecast during machining since there are too many factors that control it. They are the two sets of factors: work-related materials and physical properties of the material. Microstructure, grain particle sizes, heat treatment, chemical properties, processing, stiffness, yield strength, and tensile strength are the eight factors that make up the work content, and the physical properties are modulus of elasticity, thermal conductivity, thermal expansion, and work hardening. Operating environments, cutting instrument content and geometry, and machining operation specifications are also critical considerations. Other important factors include operating conditions, cutting tool material and geometry, and machining process parameters. The process converts working materials from one shape to the next by adding value through machining. Machining is the collection of the process where the cutter removes the material in the form of a chip. Relative motion between both the workpiece and tool is needed to achieve this.

The working materials are divided into metals and nonmetals. Metals are iron, aluminum, gold, silver, copper, lead, pewter, magnesium, titanium, zinc and nickel, mercury,

*E-mail address: doctorgmahesh@gmail.com ISSN: 1791-2377 @ 2021 School of Science, IHU. All rights reserved. doi:10.25103/jestr.142.16 tungsten, alloy metals: stainless steel, carbon steel, duplex stainless steel, brass and bronze. Non-metals are plastics, wood, glass, polymers, ceramics, synthetic fibers, composites. The metals are divided into ferrous and nonferrous metals. Although ferrous materials have great applications in the engineering field. Besides, ferrous materials are categorize into cast iron, ductile iron, malleable iron, gray irons, austempered ductile iron, compacted graphite iron, white iron, carbon steels: High-Carbon, medium-Carbon, low carbon, and alloy steels: Low-alloy steels, High strength low alloy steels, Micro Alloyed Steels, Advanced High - strength steels, Maraging steels, Stainless steels. Nowadays the non-ferrous materials such as ceramics, composite materials, and plastics place an outstanding and have sprung up in various applications in the field of engineering due to their physical, mechanical and chemical properties. At the time of steel production, the process involved oxidation with a minimum combination of chrome of about $10.50 \%$, manganese of about $01.65 \%$, silicon of about $0.60 \%$, or copper of about $0.60 \%$ and other alloys known as alloy steel. One of the alloy steels known as stainless steels is a very tremendously useful material in engineering applications; it offers high toughness, stiffness and durability. Low-alloy steel includes less than $8 \%$ of the total alloy added, whereas high-alloy steel contains more than $8 \%$ of the total alloy added. Austenitic, ferritic, duplex, martensitic, and precipitation hardened stainless steels are classified into five groups depending on their crystalline form. In addition duplex stainless steel (DSS) is a new and 
rapidly growing family. Duplex stainless steels contain chromium, nickel and molybdenum and It's quenched with water at a high operating temperature, resulting in a microstructure that's around half austenite and half ferritic. The ferritic content is $50 \%$. The figure 1 and 2 shows the longitudinal and transversal direction of microstructure of Sandvik SAF 3207 HD tube material and figure 3 shows the grain structure in a SAF 3207 HD umbilical tube [1]. Color grains are austenitic phase and grey grains are ferritic phase. DSS is specifically intended for stress corrosion cracking induced by surface infectivity by iron and pitting corrosion caused by chloride, and is engineered to provide improved good durability, higher yield strength, and greater corrosion resistance.

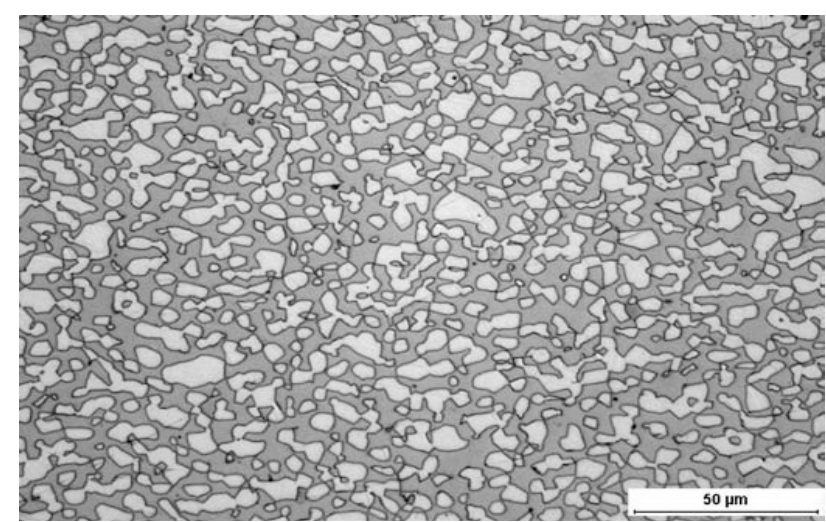

Fig.1. Longitudinal direction Microstructure of Sandvik SAF 3207 HD tube material. The white phase is called austenite, and grey phase is called ferrite: (Source: Guocai Chai et al, (2009), Sandvik Materials Technology)

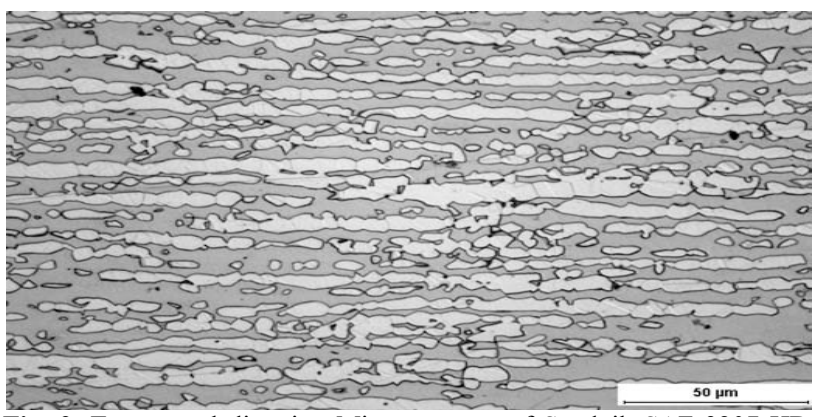

Fig. 2. Transversal direction Microstructure of Sandvik SAF 3207 HD tube material. The white phase is called austenite, and grey phase is called ferrite: (Source: Guocai Chai et al, (2009), Sandvik Materials Technology)

The chemical composition of 18 to $30 \%$ chromium is added to increase corrosion resistance, although the increase in chromium ferrite content also increases by forming dispersed second-phase carbides. 4 to $8 \%$ nickel is added to change the crystalline structure of ferrite to austenite and it has increased toughness and impact resistance. Figure 4 shows how increasing nickel content affects the microstructure of a stainless steel from ferritic to duplex to austenitic. The addition of less than 5\% molybdenum improves pitting corrosion resistance and makes the material avoid brittleness. A minimum of $0.14 \%$ nitrogen is added to increase the corrosion resistance of pitting and crevices. Zirconium, cerium and calcium may also enhance toughness. Forming manganese sulfides by incorporating lead, bismuth, selenium, or tellurium may increase machinability. Other compounds, on the other side, may be used to minimize ferrite or austenite in grain.

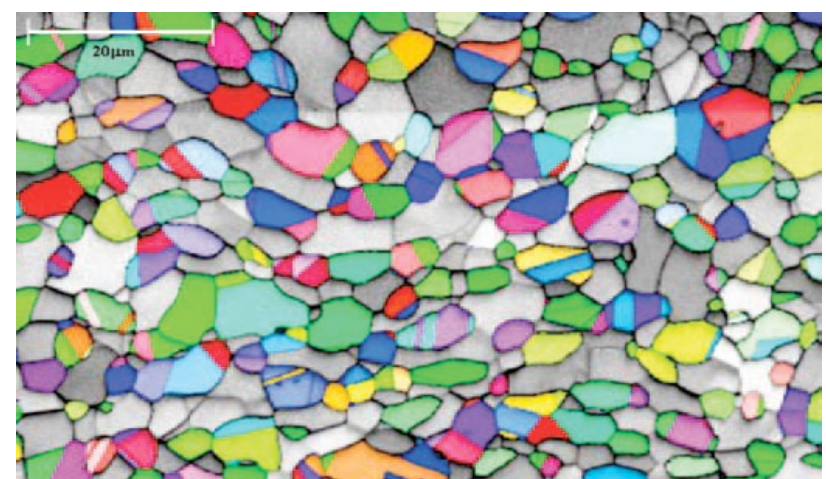

Fig. 3. Grain structure in a SAF 3207 HD umbilical tube Austenitic phase - Color grains are ferritic phase - grey grains. (Source: Guocai Chai et al, (2009), Sandvik Materials Technology)

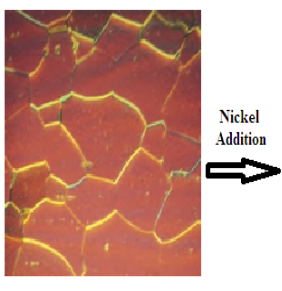

Ferritic structure

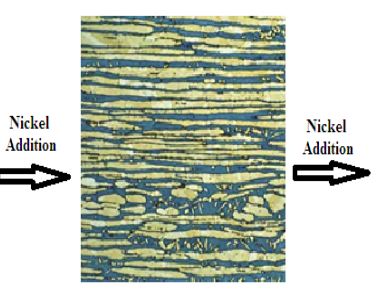

Duplex structure

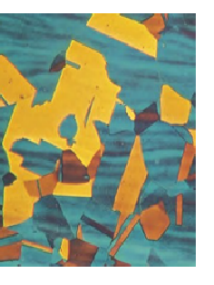

Austenitic structure
Fig. 4. The microstructure of a stainless steel transitions from ferritic to duplex to austenitic as the nickel content rises. (source: IMOA International Molybdenum Association, 2014)

\section{Types of DSS and their properties.}

Duplex Stainless Steel primarily divided into four basic alloy categories ranging from Lean DSS (LDSS), Standard DSS (Std DSS), Super DSS (SDSS) and Hyper DSS (HDSS).

\subsection{Lean Duplex Stainless Steel (LDSS)}

Lean DSS (LDSS) contains a higher percentage alloy blend of chromium, a lower level of molybdenum and nickel. Nitrogen is applied to alloys with low nickel concentrations to increase austenite content. To lower the expense of the LDSS content, a small amount of molybdenum and nickel is applied. It offers to pitting resistance equivalent number (PREN) of approximately 26. [2] stated that nitrogen is added to provide a concentration of austenites in alloys. Due to the reduction in carbon content and the high chrome content, the machining and welding are much easier than other grades. The LDSS has a strong degree of mechanical efficiency, corrosion tolerance, and tensile deterioration resistance to cracking, as well as decent weldability and durability. The LDSS categories are S32001, S32101, S32202, S32304, S82011, S82012, S82122, Molybdenum-containing lean duplex are S32003, S81921, S82031, S82121, S82441, Er.no 1.4655. 1.4669,316L. Lean DSS materials are needed for applications that require high strength, such as construction projects, storage tanks, containers, etc., which requires long-term corrosion resistance is needed.

\subsection{Standard Duplex stainless steel (DSS)}

The standard duplex stainless steel microstructure has almost equal ratios of austenite and ferrite and is thermally treated properly during production. Their characteristics are twice as high as those of other austenite stainless steels for excellent toughness, mechanical strength and high yield strength [3]. Standard DSS includes more than chromium $22 \%$, molybdenum 3\%, nickel 5-6\% and nitrogen, whose 
microstructure guarantees greater stress-corrosion cracking tolerance, greatly improves pitting and crevice-corrosion resistance in the presence of chloride, and provides good resistance to hydrogen sulphide stress corrosion. It provides a Pitting Resistance Equivalent Number (PREN) of about 35. The temperature at which normal DSS transitions from ductile to brittle is $-50 \mathrm{oC}$, and it embitter between $300 \mathrm{oC}$ and $550 \mathrm{oC}$ after its properties shift, forming sigma and chi phases between $550^{\circ} \mathrm{C}$ and $1000^{\circ} \mathrm{C}$.

The application temperature of the standard DSS should therefore range from $-50^{\circ} \mathrm{C}$ to $300^{\circ} \mathrm{C}$. S31803, S32205, S32950, and S32808 are the regular DSS types. Normal DSS uses include digesters for the pulp and paper industry, bleaching machines, thermal exchangers in the chemical manufacturing industry, pressure reservoirs, reservoirs, plumbing and pipes, tubing and gas and oil handling, and stock handling devices, rotors, fans, blades, and pressing rolls, freight tanks for ships and vehicles, food processing machinery, and so on.

\subsection{Super Duplex stainless steel (SDSS)}

Duplex is a mixed microstructure of austenite and ferrite $(50 / 50)$ that has increased the stability and durability of ferritic and austenitic steels. Super Duplex Stainless Steel (SDSS) is a mixed microstructure of austenite and ferrite $(50 / 50)$ that has improved the resistant of ferritic and austenitic steels. The biggest distinction is that the super duplex produces a higher amount of molybdenum (3-4\%), chromium (24-26\%), and nickel (5.5-8\%). The need for smaller thicknesses and low costs without compromising quality and lighter materials with higher mechanical and chemical properties resulted in the more frequent use of SDSS. The resistance to corrosion, tensile, yield strength, ductility, toughness and stress corrosion cracking resistance is higher than other duplex stainless steel. The SDSS is produced using an isothermal aging treatment at temperatures between $400^{\circ} \mathrm{C}$ and $600^{\circ} \mathrm{C}$ and a processing time between 3 to 120 hours. Super duplex stainless steels (SDSS) have a PREN of more than 40. S32506, S32520, S32550, S32750, S32760, S32906, S39274, and S39277 are the mega DSS groups. Super Duplex is used in the oil and gas industry in heat exchangers, chemical refining devices, pressure vessels, and boilers, and is ideal for usage in hostile conditions such as hot acidified ocean water and toxic environments with chloride.

\subsection{Hyper Duplex stainless steel (HDSS)}

Hyper duplex is also known as HDSS and the latest type of two-phase stainless steel. Hyper DSS has about 25.08 percent chromium, 3.82 percent molybdenum, 6.880 percent nickel, and 0.5 percent nitrogen and has the highest corrosion resistance, strength, and mechanical properties, including improved tensile and fatigue resistance, resistance to both chlorine and sulfur stress cracking, erosion-corrosion, and general acid corrosion resistance. The SDSS is made by aging it at temperatures ranging from $(800-1300)^{\circ} \mathrm{C}$ in an isothermal setting. Hyper duplex stainless steel is described as having a PREN value of around 50. S32707 and S33207 are two Hyper DSS groups. The HDSS has been developed to address the growing demand for chemicals, deep umbilical waters, oil and gas industries. The DSS family of chemical composition, pitting resistance equivalent number (PREN) and material used to conduct experimental work is given in Table 1 [4].

\section{Machining of DSS}

Owing to fragmentation, heat creation inducing plastic deformation during manufacturing, and severe wear craters, duplex steels are more complicated to process in general. The aim of this article is to review recent research on duplex stainless steel in the field of metal cutting in the turning phase, as well as optimization methods for predicting various performance dependable factors such as surface roughness, cutting power, machinability, chip volume ratio, and material removal rate over the last decade. The international conference was held in Grado, Italy, in 2007 to investigate the recent developments in the field of duplex stainless steel [5], unfortunately, no paper is examined in the field of metal cutting and optimization methods used to predict various output dependable factors. The researchers conducted experimental work by using duplex stainless steel material to predict surface unevenness, wear in tool, machinability, MRR and chip volume ratio is shown in Table 2. Various factors used in experimental work and optimization of DSS are shown in Table 3.

\subsection{Factors affecting Surface Roughness}

Cutting criteria, as well as the condition and grain texture of the working material, decide the surface quality of the machined component. Surface roughness is a vital metric for measuring cutting efficiency in turning operations. The greatest emphasis has been placed on research in the area of superficial roughness in the previous decade, to obtain the maximum level of surface finishing, various optimization techniques were used.

Table 1. Family of DSS with Chemical Composition (Source: IMOA - International Molybdenum Association)

\begin{tabular}{|c|c|c|c|c|c|c|c|c|c|c|c|c|}
\hline $\begin{array}{l}\text { Types of } \\
\text { DSS }\end{array}$ & $\begin{array}{c}\text { Grade/Commercial } \\
\text { Name-DSS }\end{array}$ & $\begin{array}{c}\text { UNS } \\
\text { Number- } \\
\text { DSS }\end{array}$ & $\begin{array}{l}\text { EN Nr.- } \\
\text { DSS }\end{array}$ & $\begin{array}{c}\text { C- } \\
\text { Carbon }\end{array}$ & $\begin{array}{c}\text { Cr- } \\
\text { Chromium }\end{array}$ & $\begin{array}{c}\text { Ni- } \\
\text { Nickel }\end{array}$ & $\begin{array}{c}\text { Mo- } \\
\text { Molybdenum }\end{array}$ & $\begin{array}{c}\mathrm{N}- \\
\text { Nitrogen }\end{array}$ & $\begin{array}{c}\text { Mn- } \\
\text { Manganese }\end{array}$ & $\begin{array}{c}\text { Cu- } \\
\text { Copper }\end{array}$ & W & PREN \\
\hline \multirow{3}{*}{$\begin{array}{c}\text { First } \\
\text { generation } \\
\text { duplex } \\
\text { stainless steel }\end{array}$} & 329 & S32900 & 1.4460 & $.08 \%$ & $23 \%-28 \%$ & $2.5 \%-5 \%$ & $1 \%-2 \%$ & - & $1 \%$ & - & - & 30 to 31 \\
\hline & 3RE60 & S31500 & 1.4424 & $.03 \%$ & $18 \%-19 \%$ & $\begin{array}{l}4.3 \%- \\
5.2 \%\end{array}$ & $2.5 \%-3 \%$ & $.05 \%-.10 \%$ & - & - & - & 28 to 29 \\
\hline & 324 & S32404 & & $.04 \%$ & $20.5 \%-22.5 \%$ & $\begin{array}{l}5.5 \%- \\
8.5 \%\end{array}$ & $2 \%-3 \%$ & $.20 \%$ & $2 \%$ & $1 \%-2 \%$ & - & 29 to 30 \\
\hline \multirow{10}{*}{$\begin{array}{l}\text { Lean duplex } \\
\text { stainless steel }\end{array}$} & A789 & S32001 & 1.4482 & $.03 \%$ & $19.5 \%-21.5 \%$ & $1 \%-3 \%$ & $.6 \%$ & $.05 \%-.17 \%$ & $4 \%-6 \%$ & $1 \%$ & - & 21 to 23 \\
\hline & LDX 2101 & S32101 & 1.4162 & $.04 \%$ & $21 \%-22 \%$ & $\begin{array}{c}1.35 \%- \\
1.7 \%\end{array}$ & $.1 \%-.8 \%$ & $.20 \%-.25 \%$ & $4 \%-6 \%$ & $.1 \%-.8 \%$ & - & 25 to 27 \\
\hline & A815 & S32202 & 1.4062 & $.03 \%$ & $21.5 \%-24 \%$ & $1 \%-2.8 \%$ & $.45 \%$ & $.18 \%-.26 \%$ & $2 \%$ & - & - & 25 to 28 \\
\hline & EDX 2304 & S32304 & 1.4362 & $.03 \%$ & $21.5 \%-24.5 \%$ & $3 \%-5.5 \%$ & $.05 \%-.6 \%$ & $.05 \%-.2 \%$ & $2.5 \%$ & $.05 \%-.6 \%$ & - & 25 to 28 \\
\hline & ATI 2102 & S82011 & - & $.03 \%$ & $20.5 \%-23.5 \%$ & $1 \%-2 \%$ & $.1 \%-1 \%$ & $.15 \%-.27 \%$ & $2 \%-3 \%$ & $.5 \%$ & - & 25 to 27 \\
\hline & FDX 25 & S82012 & 1.4635 & $.05 \%$ & $19 \%-20.5 \%$ & $0.8 \%-$ & $.10 \%-.6 \%$ & $.16 \%-.26 \%$ & $2 \%-4 \%$ & $1 \%$ & - & 24 to 26 \\
\hline & NSSC 2120 & S82122 & - & $.03 \%$ & $20.5 \%-21.5 \%$ & $\begin{array}{l}1.5 \%- \\
2.5 \%\end{array}$ & $.6 \%$ & $.15 \%-.2 \%$ & $2 \%-4 \%$ & $.50 \%-1.5 \%$ & - & 24 to 26 \\
\hline & A815 & S31803 & 1.4655 & $.03 \%$ & $22 \%-24 \%$ & $\begin{array}{l}3.5 \%- \\
5.5 \%\end{array}$ & $.1 \%-.6 \%$ & $.05 \%-.2 \%$ & $2 \%$ & $1 \%-3 \%$ & - & 25 to 27 \\
\hline & & - & 1.4669 & $.045 \%$ & $21.5 \%-24 \%$ & $1 \%-3 \%$ & $.5 \%$ & $.12 \%-.2 \%$ & $1 \%-3 \%$ & $1.6 \%-3 \%$ & - & 25 to 27 \\
\hline & $316 \mathrm{~L}$ & - & 1.4404 & $.03 \%$ & $16.5 \%-18.5 \%$ & $10 \%-$ & $2 \%-2.5 \%$ & $\leq 0.11 \%$ & $2 \%$ & - & - & \\
\hline
\end{tabular}




\begin{tabular}{|c|c|c|c|c|c|c|c|c|c|c|c|c|}
\hline & & & & & & $13 \%$ & & & & & & \\
\hline \multirow{5}{*}{$\begin{array}{l}\text { Molybdenum - } \\
\text { containing } \\
\text { Lean duplex } \\
\text { stainless steel }\end{array}$} & A790 & S32003 & - & $.03 \%$ & $19.5 \%-22.5 \%$ & $3 \%-4 \%$ & $1.50 \%-2 \%$ & $.14 \%-.2 \%$ & $2 \%$ & - & - & 27 to 31 \\
\hline & $\mathrm{A} 240$ & S81921 & - & $.03 \%$ & $19 \%-22 \%$ & $2 \%-4 \%$ & $1 \%-2 \%$ & $.14 \%-.2 \%$ & $2 \%-4 \%$ & - & - & 27 to 28 \\
\hline & FDX 27 & S82031 & 1.4637 & $.05 \%$ & $19 \%-22 \%$ & $2 \%-4 \%$ & $.60 \%-1.4 \%$ & $.14 \%-.24 \%$ & $2.5 \%$ & $1 \%$ & - & 27 to 28 \\
\hline & A790 & S82121 & - & $.035 \%$ & $21 \%-23 \%$ & $2 \%-4 \%$ & $.30 \%-1.3 \%$ & $.15 \%-.25 \%$ & $1 \%-2.5 \%$ & $.2-1.2 \%$ & - & 27 to 28 \\
\hline & LDX 2404 & S82441 & 1.4662 & $.03 \%$ & $23 \%-25 \%$ & $\begin{array}{l}3 \%- \\
4.5 \% \\
\end{array}$ & $1 \%-2 \%$ & $.20 \%-.30 \%$ & $2.5 \%-4 \%$ & $.1 \%-.8 \%$ & - & 33 to 34 \\
\hline \multirow{4}{*}{$\begin{array}{c}\text { Standard } \\
\text { duplex } \\
\text { stainless steel }\end{array}$} & 2205 & S31803 & 1.4462 & $.03 \%$ & $21 \%-23 \%$ & \begin{tabular}{|c|}
$4.5 \%-$ \\
$6.5 \%$
\end{tabular} & $2.5 \%-3.5 \%$ & $.08 \%-.20 \%$ & $2 \%$ & - & - & 33to 35 \\
\hline & 2205 & S32205 & 1.4462 & $.03 \%$ & $22 \%-23 \%$ & $\begin{array}{c}4.5 \%- \\
6.5 \%\end{array}$ & $3 \%-3.5 \%$ & $.14 \%-.20 \%$ & $2 \%$ & - & - & 35 to 36 \\
\hline & A473 & S 32950 & - & $.03 \%$ & $26 \%-29 \%$ & $\begin{array}{c}3.5 \%- \\
5.2 \%\end{array}$ & $1 \%-2.5 \%$ & $.15 \%-.35 \%$ & $2 \%$ & - & - & 36 to 38 \\
\hline & DP28W & S32808 & - & $.03 \%$ & $27 \%-27.9 \%$ & $\begin{array}{l}7 \%- \\
8.2 \%\end{array}$ & $.8 \%-1.2 \%$ & $.30 \%-.4 \%$ & $1.1 \%$ & - & $\begin{array}{c}2.1 \%- \\
2.5 \%\end{array}$ & 36 to 38 \\
\hline \multirow{8}{*}{$\begin{array}{l}\text { Super duplex } \\
\text { stainless steel }\end{array}$} & NAS 64 & S32506 & - & $.03 \%$ & $24 \%-26 \%$ & $\begin{array}{c}5.5 \%- \\
7.2 \%\end{array}$ & $3 \%-3.5 \%$ & $.08 \%-.2 \%$ & $1 \%$ & - & $\begin{array}{l}.05 \%- \\
.30 \%\end{array}$ & 40to 42 \\
\hline & F255 & S 32520 & 1.4507 & $.03 \%$ & $24 \%-26 \%$ & $\begin{array}{c}5.5 \%- \\
8 \%\end{array}$ & $3 \%-4 \%$ & $.20 \%-.35 \%$ & $1.5 \%$ & $.50 \%-2 \%$ & - & 40 to 43 \\
\hline & 255 & $\mathrm{~S} 32550$ & 1.4507 & $.04 \%$ & $24 \%-27 \%$ & $\begin{array}{c}4.4 \%- \\
6.5 \%\end{array}$ & $2.9 \%-3.9 \%$ & $.10 \%-.25 \%$ & $1.5 \%$ & $1.5 \%-2.5 \%$ & - & 38 to 41 \\
\hline & 2507 & S 32750 & 1.4410 & $.03 \%$ & $24 \%-26 \%$ & $6 \%-8 \%$ & $3 \%-5 \%$ & $.24 \%-.32 \%$ & $1.2 \%$ & $.5 \%$ & - & 40 to 43 \\
\hline & F55 & S 32760 & 1.4501 & $.03 \%$ & $24 \%-26 \%$ & $6 \%-8 \%$ & $3 \%-4 \%$ & $.20 \%-.3 \%$ & $1 \%$ & $.5 \%-1 \%$ & $\begin{array}{c}0.5 \%- \\
1 \%\end{array}$ & 40 to 43 \\
\hline & SAF 2906 & S32906 & 1.4477 & $.03 \%$ & $28 \%-30 \%$ & $\begin{array}{c}5.8 \%- \\
7.5 \%\end{array}$ & $1.5 \%-2.6 \%$ & $.30 \%-.4 \%$ & $.8 \%-1.5 \%$ & $.8 \%$ & - & 41 to 43 \\
\hline & & S39274 & - & $.03 \%$ & $24 \%-26 \%$ & $6.8 \%-8 \%$ & $2.5 \%-3.5 \%$ & $.24 \%-.32 \%$ & $1 \%$ & $.20 \%-.8 \%$ & $\begin{array}{c}1.5 \%- \\
2.5 \%\end{array}$ & 40 to 42 \\
\hline & A790 & S39277 & $2-$ & $.025 \%$ & $24 \%-26 \%$ & $\begin{array}{c}6 . \% 5- \\
8 \% \\
\end{array}$ & $3 \%-4 \%$ & $.23 \%-.33 \%$ & $.80 \%$ & $1.2 \%-2 \%$ & $\begin{array}{l}.8 \%- \\
1.2 \% \\
\end{array}$ & 40 to 42 \\
\hline \multirow{2}{*}{$\begin{array}{l}\text { Hyper duplex } \\
\text { stainless steel }\end{array}$} & SAF $3707 \mathrm{HD}$ & S32707 & - & $.03 \%$ & $26 \%-29 \%$ & \begin{tabular}{|c|}
$5.5 \%-$ \\
$9.5 \%$
\end{tabular} & $4 \%-5 \%$ & $.3 \%-.5 \%$ & $1.5 \%$ & $1 \%$ & - & 49 to 50 \\
\hline & SAF 3207 HD & S33207 & - & $.03 \%$ & $29 \%-33 \%$ & $6 \%-9 \%$ & $3 \%-5 \%$ & $.40 \%-.6 \%$ & $1.5 \%$ & $1 \%$ & - & 52 to 53 \\
\hline
\end{tabular}

The experimental work is carried out by considering the different cutting speed, the rate of feed with a constant cutting depth of S32205 and S32750 duplex cast stainless steels using Titanium Carbo Nitride coated cemented carbide and Titanium carbide tools. The author suggests that during the experiment of texture analysis, the increasing cutting speed decreases the roughness of the surface, the roughness of the surface decreases with decreasing feed speed [6]. The experiment was conducted to analyze the hardness of duplex coated carbide tools during the machining of 1.4462 steel using statistical techniques. Hardness measurements were carried out at varying cutting speeds and under both wet and dry environments. [7]. The author [8] built a mathematical model using the Response surface method to quantify surface roughness while turning the DSS using the turning mechanism, taking into account cutting speed, feed, and cutting depth. The main factor influencing surface roughness, according to the source, is feed velocity. The cutting pace, rate of feed, and cutting depth of SAF 2507 super duplex stainless steel bars were measured using uncoated carbide cutting equipment, with the feed rate being the parameter that has the largest effect on surface roughness. The work is designed and the analysis is conducted using variance analysis (ANOVA) and the surface roughness and $\mathrm{S} / \mathrm{N}$ ratio were measured using the L18-Taguchi method during optimization. [9]. The ANOVA statistical technique is used to identify significant variables and optimization was performed using the full factorial design of Taguchi experiments to measure surface roughness. The super duplex SAF 2507 stainless steel bars with uncoated carbide cutters are used in turning operation. Cutting speed, feed speed and cutting depth are the parameters used in wet, dry and gascooled cutting conditions to optimize surface roughness and tool wear. When liquid $\mathrm{CO}_{2}$ is used as a coolant, the surface unevenness and flank wear on the tool are minimized, according to the results [10]. The evaluation made by the author [11] to compare the EN (1.4404) austenitic steels, duplex standard EN (1.4462) and super duplex EN (1.4410) in turning operation by facilitating ANOVA and optimized using the Taguchi coupled with fuzzy-multiple attribute decision-making methods (FMADM). The ANOVA predicted that the feed speed is an impact on surface quality and finally concluded that EN 1.4404 stainless steel was best considered for machining the part. The experiment is performed by considering the cutting speed and low and high fluid pressure cooling conditions of the super duplex UNS32750 stainless steel to determine the parameters that have the greatest impact on corrosion resistance. The results indicate that extended life of tool, good surface unevenness and high resistance due to corrosion is achieved while turning with high-pressure-cooled PVD - physical vapor deposition coated inserts [12]. The study was conducted using dry machining of duplex stainless steel to determine surface roughness using the load curve with different cutting speeds, feed and cutting depth according to cutting conditions using TNMG 160408 cutting tool inserts and detected that rate of feed is the major parameter influencing surface unevenness [13]. An experiment was conducted by [14] to reduce surface roughness and cutting force using 2205 DSS material and multilayer milling cutter PVD CNMG 120408 SM grade 1115 by taking into an account of cutting speed, rate of feed, cutting depth and tool nose radius. The optimization was performed using ANOVA, BBD and RSM. The author suggests that an increase in the speed, rate of feed influences the roughness of the surface. The author optimized the machining parameter: cutting speed, rate of feed and cutting depth to predict surface unevenness and force due to cutting of cast material DSS ASTM grade $9954 \mathrm{~A}$ and 5A utilizing the Taguchi and ANOVA method. The outcomes revels that rate of feed is the most considerable parameter that affects the surface unevenness and cutting force [15]. Wet and dry longitudinal turning tests are carried out using duplex grades of stainless steel $\mathrm{EN}(1.4462)$ and $\mathrm{EN}(1.4410)$ using carbide inserts to analyze the unevenness of the surface, the wear in the tool, the forces, the power using the input variables: feed, cutting speed and cutting conditions. The optimization technique called bat algorithm is used to achieve multi-objective optimization of adversarial performance. The author ensures the most appropriate cutting configuration for making efficient turning operation [16]. The EN (1.4404), EN (1.4462) and EN (1.4410) duplex material are considered for turning operation, the ANOVA analysis is carried out to model the performance characteristics. The MADM methods such as GTMA and AHP - Technique for order preference by 
similarity to ideal Solution (AHP-TOPSIS) are simultaneously adapted to associate well-known surface excellence features into a single index called MSQCI .The author suggested that the performance of multiple machining and surface qualities could be optimized efficiently using MADM methods are coupled to the fuzzy set theory [17]. The author [18] tested different rate of feed and cutting speeds using SAF 2507 DSS materials and concluded that the maximum surface finish is achieved with a high cutting speed and lower rate of feed. The turning operation is formed using 1.4462 duplex stainless steel, to analyze the optimal machining conditions, which cut back pollution generated by the coolant and lubricant. The surface unevenness, cutting force and tool wear are analyzed. The results indicate that higher parameters necessary to energy consumption minimization will also result in an increase in surface unevenness [19]. The cutting operation is accomplished on the SAF2507 duplex stainless steel by considering the cutting speed, feed and cutting depth to analyze the wear of the tool and the roughness of the surface. The comparison is done by the author [20] of three PVD coating tool: TiAlSiN, AlTiN and AlTiN using HiPIMS method, results shows that the presence of the buildup edge for the surface roughness are aggravated at a slower speed. Dry and wet turning work are carried out [21] to examine the effect of the cutting fluid and lubricant using the MQCL turning process to ensure the clean production of DSS (1.4462) by using the surface morphology examination using an IFM and found that MQCL cooling improves surface effects over dry machining. Researcher [22] performed the experiment using the super duplex EN (1.4410) to analyze the machinability and surface roughness using a cooling and lubrication fluid. ANOVA was used to create the mathematical model, RSM was used to create the predictive model, and GA was used to optimize the model. When machining DSS 2205 in a conventional turning unit, the author [23] looked at the impact of surface unevenness and tool wear. Comparison of machining output between normal coolant and cold air coolant using TiAlN coated carbide with constant cutting pace, feed, and cutting depth. In comparison to the traditional flood coolant, the findings indicate that the cooled air coolant generated a better surface finish. The TiAlSiN PVD coated tool (3.3 micrometer), AlTiN (3.0 micrometer), and AlTiN (7.0 micrometer). To test tool life and surface roughness, the super DSS (2507) material is used under dry cutting conditions with parameters such as cutting pace, rate of feed, and cutting depth. The authors [25] have developed a strategy for the best combination of tool geometries, feed, coolant used to increase life of tool life, productivity, to reduce surface roughness. The longitudinal, tapered section is made using UNS S32750 DSS. This results in the shortest life of the tool life and lowest roughness values for longitudinal cuts with reduced feed rates. Using ANOVA and the Taguchi L9 orthogonal matrix, a predictive model is created to determine the surface texture of 2205 DSS content. Cutting speed, rate of feed, and approach angle are all seen as input process parameters. For longitudinal cuts with decreased feed speeds, this result is the shorter tool life and the lowest roughness values [26]. S32205 is a nitrogen alloyed DSS that was used in this study. Input parameters include cutting tempo, feed rate, and cutting depth. The mathematical model is developed using ANOVA and optimization is performed using the Taguchi technique to forecast surface unevenness. The researcher proposes that rate of feed is the most significant variable that affect surface unevenness [27]. The author [28] developed a predictive model by means of ANOVA and
RSM to examine the interaction effect of each parameter: cutting speed, feed, cutting depth of EN 1.4410 super duplex stainless steel. The ANFIS is convened using fuzzy logic systems. Lastly, the accuracy of the predictive models is based on comparative examination and concludes that feed speed has the greatest effect on surface unevenness. In dry and cryogenic conditions, turning operations were performed on the DSS 2205 using PVD coated nano-multilayer TiAlN. As opposed to dry spinning, cryogenic cooling improves roughness by around 18-23 percent [29]. The machining is performed by means of vegetable oil (Neem and Coconut oils) as cutting fluid to measure surface roughness, tool wear and tool temperature, while turning AISI 2205 DSS, considering the spindle speed, feed rate, cutting depth and type of cutting fluid. The Taguchi L27 methodology is used to improve the parameters. Coconut oil-based cutting fluid was found to be more effective at increasing surface roughness [31] analyzed the M.R.R, surface unevenness, feed rate, thrust force and cutting force using Duplex 2205. The author concluded that surface roughness are high in high spindle speed and cutting depth by considering the spindle rate, feed rate, and depth of cut, of turning operation. The analysis is carried out using DOE, ANOVA and RSM. The experiment was carried out using SAF 2507 - DSS to measure the surface texture, using RSM and ANN technique. The validation is done by the author using a genetic algorithm. The findings show that perhaps the feed rate has been the most important element in reducing surface quality [32]. The researcher [33] performed the study to determine the impact of surface unevenness and residual stresses on coated and uncoated carbide tools. The experiment conducted under dry working condition and material considered for turning is 2205 Duplex Stainless Steel and cutting tool as Cemented carbide tools. The effect of reduced surface unevenness was three times greater in uncoated tools than in coated tools. The experimental work is performed by [34] to focuses on the practical analysis to turn SDSS UNS S32760 with nano-coated MEGACOAT carbide insert. The surface unevenness, force due to cutting and MRR are analyzed using ANOVA and the results are optimized using Taguchi Analysis to predict the experimental values. The result emphasized that the feed rate is a predominant constraint for Ra. Machining carried out under dry turning to examine surface unevenness, MRR by considering velocity due to cutting, rate of feed and approach angle. ANOVA was used for mathematical research, and the Taguchi process of the DSS material was used to refine the WC-Co coated carbide inserts.

The findings showed that the rate of feed is the most influential parameter [35]. The author [36] discussed an impact on cutting speed, rate of feed and cutting depth to analyze the characteristics of cutting force, surface unevenness and MRR when turning UNS S32760 SDSS using nano-plated MEGACOAT carbide inserts. The ANOVA and Taguchi experimental design helps predict factors. The relationship analysis in Taguchi gray is carried out for simultaneous optimization. The findings indicate that the feeding rate is a dominant constraint for Ra. Experiments were carried out using SDSS- 2507 and a handled cryogenic instrument, with cryogenic coolant explicitly passing through the insert of the changed cutting tool. The findings are compared to those of dry cutting. The effect of cryogenic coolants LN2 injected into holes drilled in the tungsten carbide cutting tool's flank and rake surfaces. Chip breaking is strong in cryogenic machining, which decreases friction between the device and tool interface while 
maintaining a good dimensional accuracy [37]. The impact of TiAlN and TiN coated drills, as well as cutting criteria, on drilling performance was examined. In the tests used to quantify cutting force and surface roughness, various cutting speeds and rate of feed were used. An experiment was performed under FFD conditions and optimal situations were determined from the values measured by the GRA method. In addition, ANOVA method was conducted. The feeding rate is calculated to be the most significant element on $\mathrm{Ra}$ dependent on the ANOVA data. [38]. In this current work, [39] 2507 super duplex stainless steel was used to examine the carbide inserts have a multilayer coating of MT-TiCN/ A1203.The experiment was conducted at a constant cutting rate and cutting depth. Five different feeding rates were used - Poor surface finishing resulting from dry cutting resulted in higher stress concentration and chloride accumulation in the surface defect area. The use of MQL has improved the surface finish which has helped reduce pit formation. All tests were conducted on a SDSS 2507 hot-forged material. Cutting with CCMT120408MR style inserts is advised, implying that there is an optimum pace beyond which surface roughness does not deteriorate [40]. Wear in the instrument, cutting power, and surface unevenness were all measured when dry turning DSS 2205 with tungsten carbide inserts coated with AlTiCrN and AlTiN. Magnetron with a High Power Impulse Under dry spinning, the sputtering method was used with various cutting speeds, feeds, and a set depth of cut of $0.8 \mathrm{~mm}$ as cutting parameters. The lower surface finish was caused by a mixture of high speed $(180 \mathrm{~m} / \mathrm{min})$ and low feed $(0.12 \mathrm{~mm} / \mathrm{rev})$ [41].

\subsection{Factors affecting Tool wear}

The process of wear and tear of the tool depends mainly on the cutting parameters. The wear of the tool point causes worsening in the superiority of the machined surface and therefore reduces effectiveness and production. Irregular wear and accumulated edge (BUE) often occur during processing of duplex stainless steel because of its properties, namely high robustness, low thermal conductivity and a high degree of work strengthening. There are various kinds of wear of the tools during machining. Fatigue-induced failure, diffusion wear, wear in flank, crater wear, notch wear, abrasive wear, wedge wear, notch wear etc. The investigational study is conducted to observe the wear on tool by means of abrasive wear mechanisms, fatigue-induced failure mechanisms and wear mechanisms of the adhesive and diffusion made of duplex 2205 stainless steel. Tin-coated HSS and Tin - coated cemented tools are used for machining purposes. To minimize tool wear, the study concluded that tin-coated HSS is used at low cutting speeds [42]. The experiment was carried out with a X2CrNiMo22-5 (2205) stainless steel duplex cutting tool using DNMG $150608 \mathrm{MF}$ and the cutting factors are the advance, the cutting depth and cutting speed. Cutting force, surface unevenness and wear in the tool are tested. The experiment is conducted by means of a high-pressure water jet assisted turning [43]. The results indicate that chip fragmentation is fine, and tool lifetime is increased. The researcher [44] investigated tool wear behavior during machining of 2507 - SDSS, 2205 Std DSS and 2101 - LDSS. The wear of the cutting tool, in many serious belongings, has been observed to a certain level on all the dissimilar cutting data is studied. The researcher [45] conducts the research using stainless steel Austenitic ferritic (Duplex) tempered PH. The comparison is performed using four different ceramic cutting tools based on alumina to determine the size of the surface unevenness and life of the tool. The flange, crater and notch wear are studied. The mathematical model is developed by using multi-regression analysis and analyzed by ANOVA. The aim of the study was to find the turning variables affected the reduction of flank wear rate and chip formation. The working material and tools are made of 2507 - SDSS, an uncoated carbide tool. Cutting speed, rate of feed and cutting depth serve as variables to measure flank wear. The optimization was performed using the RSM [46]. The study was conducted by [47] to fix the coated carbide tool surface structure. The cutting material is 1.4462 - DSS and cutting tool inserts are TNMG 160408 taken to do turning operation. The tool wear study examines the wear of the wedge on the rake face as well as the outline of the cutting point. SEM analysis is used to examine the rake and flank wear of the cutting tool, and the results show that cutting edge wear raises as cutting speed increases [48]. The author [49] observes the impact of the cutting parameters: cutting speed, the advance and the cutting depth on the life of the tool in the DSS turning process. This experiment is carried out using DSS (1.4462) using TNMG 160408 as cutter. The factor design of an experiment is used to forecast the lifetime of the tool. The established equations and concluded that cutting speed is the major influencing factor that affect the life of the tool. The author [50] carried out an experimental study in two phases considering 1.4410 EN SDSS, 1.4462 EN DSS and 1.4404 EN austenitic steel. A new methodology based on Mamdani's fuzzy interference is used to classify chip shapes to predict the chip volume ratio. TOPSIS, GRA, VIKOR and UA method was used for optimization. The results showed that the conversion of the results of the different MADM methods is used to determine an optimal combination of cutting parameters. In the next stage, the force exerted due to cutting and current consumption signals of the machine are adopted as indirect techniques used to observe the wear of the cutting tool. The SAF 2507 SDSS is used to allow a detailed distinction between dry, wet, and gas-cooled turning. Cutting speed, rate of feed, and depth of cut are considered as input parameters. It has been revealed that gas-cooled machining performed better than wet and dry machining [51]. The author [12] emphasized experimentation to prevent wear and tear of cutting tools, suggests that the observed that notch wear affected by the chilling effect created by the burr, the use of the high-pressure cooling system has brought advantages, such as the prolonged lifetime of the tool. In the time of machining, it's important to use high-pressure cooling to ensure a long service life. The cutting speed was recognized as the greatest important factor that affects the wear in the tool. The wear on the tools was examined using a SEMI. The author suggests that the wear in the tool is owing to attrition at lower cutting speeds [15]. The study purposeful the cutting conditions of the turning 1.4462 DSS with coated carbides to predict tool life. The wear results are compared between the two tool points. The author concluded that raising the cutting speed causes the increase cutting edge to wear, particularly at higher feed speeds, and that using mineral oil-based lubricants reduces the cutting tool's durability [52]. In terms of tool wear rate, total wear depth, and tool temperature, the simulation results were obtained. While machining, the TOPSIS, VIKOR, GRA, and UA are used at the same time to maximize the average wear flow of DSS tool. In contrast to EN 1.4410, the tool wear intensity is lower than EN 1.4462 [53]. The document describes the optimization method used to predict tool wear using DSS 1.4462 (DIN EN 10088-1). Experimental design (DOE) is used to create a mathematical 
model to create the experimental data. An ANOVA examination was established to determine the significance of the processing parameters. The Taguchi method with the orthogonal matrix L9 and the signal-to-noise relationship is used to optimize. The cutting speed and rate of feed are affect the permanence of the tool [54]. The experimental work is performed [55] to optimize using dynamic programming of the cutting variables of 1.4462 - DSS. Dijkstra's modified optimization algorithm results the optimum value of cutting variables using coated carbide tool. The ANOVA method specifies that the cutting speed and feed speed affected the tool lifespan.

The aim of this research is to find out cause of tool wear and tear. images of worn areas obtained bu using SEM were included in this study. To understand the causes of tool wear using a EDS system Wear has arisen while machining super duplex stainless steels owing to a rough burr [56].The tool comparison is carried out by [57] using 2507 -SDSS by using PVD and CVD coated tools. The author accessed the wear in wear, force exerted, surface integrity and rise in temperature and according to the findings, the MT-TiCN-Al2O3 coating outperforms other coatings. As compared to chilled cooled air coolant, tool life was improved utilizing traditional flood coolant. Despite their low hardness, AlTiN coated tools outperform AlTiSiN coated inserts [23].An experimental study [24] on the 2507 SDSS with non coated and coated with PVD carbide inserts considering rate of feed, cutting speed, and dry cutting depth. The study includes the recognition of the wear mechanism of the tools on the rake and tool flank face. Cutting at a higher speed improves the cutting edge's wear strength dramatically. The usage of cemented carbide turning cutting tool inserts with CVDTiCN + Al2O3 and TiCN PVD and AlTiN coatings to the 32750 - SDSS content was explored by the author [58]. This activity suggests that AlTiN PVD coated inserts had double the tool life of $\mathrm{TiCN}+\mathrm{Al} 2 \mathrm{O} 3 \mathrm{CVD}$ coated inserts. The researcher [59] studied the tribological execution and wear mechanisms of uncoated, coated carbide tools when turning of 2507 SDSS. T chip characteristics are used to evaluate chip width, compression ratio, shear angle, and bottom surface morphology. The show that the wear mechanisms of the AlTiN coating tool perform better than the $\mathrm{TiCN}+\mathrm{A} 12 \mathrm{O} 3 \mathrm{CVD}$ insert. The author [60] discovered that the strain hardening of 2205 DSS content is highly vulnerable to cutting pace during the operation. This paper explores the process of built-up edge forming in the stagnancy area of duplex alloys in order to solve this issue. Experimental studies were carried out in the machining of S32750 DSS using uncoated and coated carbide inserts. The wear and failure mechanisms were studied during turning operations using a comprehensive tool wear analysis. The results indicate that turning with a TiAlN coating applied in PVD on a carbide insert extended the life of the tool, reduced chip thickness and improved the presence of chips below the surface [61]. The author [30] carried out experiments to observe abrasive wear and tear. According to the results, the cutting speed is high, and then there is an increase in flank wear. The cumulative edge was not shaped when the traditional insert was used in the longitudinal cut, according to Investigator [25], and flank wear stayed thin until the tool's useful life finished, before abruptly rising. Under cryogenic cooling, tool wear and saw tooth development were all minimized [29]. [62] Using G X2CrNiMoCuN 26-6-3-3 cast SDSS, PVD coated cutting inserts, TiAlN, and TiAlSiN with constant cutting speed and feed rate, an experimental test was conducted. In the machining tests, extreme burrs and build-up edge forming were found, which ruined the tool edges, according to the source. Dry machining showed the most tool flank wear, and values improved as cutting pace increased [32]. The experimental work is carried out using a feed, cutting depth and cutting speed as input parameter using molded DSS. The shape of the insert and quality of the cutting tool and technical viables of the machining, flank wear and crater wear determined [63]. In cryogenic machining, chip breakage is high, which results in less resistance between the chip-tool interfaces [37]. The effect of LN2 cryogenic coolants delivered through holes on the flank and rake surface of tungsten carbide cutter tool material in SDSS - 2507 turning using a cryogenic configuration built in-house is the focus of this study. Under dry and cryogenically cutting prepared inserts, the temperature of the cutting instrument does not alter substantially. When the LN2 is provided by a specifically adjusted insert, though, there is a noticeable change in the temperature of the cutting instrument, which has resulted in the tool having a long service life. In dry cutting, abrasion and obedience governed the wear process, resulting in increased tool wear [64]. In contrast to dry cutting, flood machining and the MQL setting decreased edge accumulation and increased tool wear efficiency by 11.95 percent and 33.08 percent, respectively [39]. The existence of AlTiCrN and AlTiN coated instruments is 6 and 4 times that of uncoated tools, respectively [41].

\subsection{Factors affecting Machinability}

DSS are considered difficult to automate. During machining processes, built-up edges and rough wear show off often. As high-strength DSS are machined, the processing problems increase. Machinability is commonly related to the stainless steel counterpart of pitting corrosion resistance, which is a value that reflects the alloy material of the steel. Modern duplex stainless steel grades are difficult to machine due to higher austenite and nitrogen content, as well as growing alloy content [65]. Tests were conducted using a DSS X2CrNiMo22-5 (2205). The authors suggest that by improving machinability characteristics, productivity improves proportionately [43]. To improve the strength of an LDSS, lowering its FN appears to be a good solution. It could be obtained by increasing the most austenitic elements $(C, N$, $\mathrm{Ni}$, and $\mathrm{Cu}$ ) and/or reducing the most ferritizing elements (Mo, Si, Cr) [66]. The authors discussed the effect of cutting parameters and conditions to calculate machinability index and effect of different tool materials is emphasized and concluded that tool wear mechanisms is the most responsible for tool failure [49], [67]. EN 1.4462 and super EN 1.4410 DSS are machined at a steady cutting pace to meet industrial requirements. The author emphasizes that reducing the cutting speed during dry cutting EN 1.4410 improves machinability. Wet cutting EN 1.4462 got a higher choice than equivalent dry cutting EN 1.4462 and wet cutting EN 1.4410 [11]. The chip forming process and machinability of two-phase materials is investigated using the wrought DSSSAF 2205 and SAF 2507. Drilling tests were carried out on a CNC machining center with solid carbide twist drills coated with (TiAlN+TiN). The highest machinability for tool wear and cutting strength is SAF 2205 [68]. To boost machinability and reliability, the author [30] proposed that vegetable oil-based cutting fluids could be a safer alternative to mineral oil. The machinability indices for DSS-2205 under liquid nitrogen cryogenic cooling worked higher than dry cutting conditions, according to experimental findings [29]. Different cooling media, such as dry cutting, flood coolant, 
and MQL, were used to examine the SDSS's machinability and surface integrity conduct [39]. The machining reliability projections indicate that increasing the nose distance increases the total secure cutting depth below which unpredictable vibrations exist, according to the researcher [40]. This observation can be used to direct the selection of cutting parameters for SDSS machining to ensure highperformance and vibration-free results. However, according to the literature, DSS is not as machinable as ASS. For dry spinning, a cemented M35 grade unglazed carbide method was used. HiPIMS has been used to cover cemented carbide substrates with AlTiN and AlTiCrN. Cutting tempo, feed, and depth are all maintained at the same level. Benchmarking requirements included nose wear, tool life, and surface roughness. Because of its high heat reliability, the AlTiCrN coated tool had a tool life 5 times longer than non-coated tools and performed higher. Due to the higher wear rate of uncoated equipment, the surface unevenness of coated tools was observed to be $1.006 \mathrm{~m}$ compared to $3.14 \mathrm{~m}$ for uncoated tools [69].

\subsection{Factors affecting Material Removal Rate (MRR)}

The material removal rate (MRR) is the volume of material extracted every minute or second. It can also be calculated by dividing the amount of material separated by the machining period [70].

$\mathrm{MRR}=\pi$. Davg. d. f. $\mathrm{N}$ in $\mathrm{mm}^{3} / \mathrm{min}$

where,

Davg - Average diameter of workpiece in $\mathrm{mm}$

D - Cutting Depth in mm

$\mathrm{f}$ - Rate of Feed in $\mathrm{mm} / \mathrm{rev}$

$\mathrm{N}$ - Rotational speed of workpiece in rpm

The authors [71] identify the most important criteria for increasing efficiency thus maintaining target product output at a low cost and shorter lead time. The tests were carried out under dry and wet conditions using ANOVA and Taguchi's mixed orthogonal network L18 to process duplex alloy steel work pieces using a cemented carbide method. Taguchi's person method was used to find the best criteria for minimal surface roughness and optimal MRR. By integrating optimization problem into an equal target, the outcomes are comparable to those produced by GRA. The key aim of this experiment is to find the best process parameters for achieving high MRR and low surface unevenness. The author came to the conclusion that when the spindle speed is strong, the MRR is high, and vice versa [31]. Ra and Fc are reduced, and MRR is maximized, to obtain the output attributes. Relational research Taguchi-grey [34] using S/N ratio review, the author [36] estimated MRR. As a consequence, the cutting forces and material removal intensity are largely defined by the depth of break. The chip volume ratio is determined by the chip shape. [50] The equation for Chip volume ratio was derived. To estimate chip volume ratio, the author developed a new technique focused on Mamdani fuzzy intervention of chip shapes classified in chip split diagrams.

$\mathrm{Qw}=\mathrm{Vc} . \mathrm{Ac}=\mathrm{Vc} . \mathrm{f} . \mathrm{a}_{\mathrm{p}}$

$\mathrm{Qsp}=\mathrm{R} . \mathrm{Qw}$

Where,

Qw - Volume of the removed material
Ac - Chip with cross sectional area

Vc - Cutting Speed

F - Rate of Feed

$a_{p}$ - Cutting Depth

$\mathrm{R}$ - Chip Volume ratio

Qsp - Volume of chips

$\mathrm{R}$-Volume needed for randomly arranged metal chips, material volume of the same amount of metal removal

A SEM was used to examine the chips produced during the process, which were optimized using three methods: dry, wet, and gaseous cooling machining. Dry machining produces constant and rippling chips, which curl inside the tool work attachment and must be withdrawn abruptly during machining. Since the chips produced in gas-cooled machining split at regular intervals and shape discontinuous chips, the tool's working interface is less affected [9]. The author [10] investigated the morphology of chips under different working conditions and came to the conclusion that gas-cooled machining is ideal for higher output ratio machining. The aim of this research was to develop a method for determining the minimum chip thickness. According to the author [72], a considerable amount of component content can only be bent on the machined surface or shape lateral flow and will not be withdrawn as a chip. An overview of soft computing techniques and optimization methods

Selecting optimal process parameters plays a significant role in ensuring quality of product, lowering manufacturing costs and increasing productivity, better surface unevenness, higher MRR and low wear in cutting tool. In the case of a turning process, the important variables to optimise are the cutting speed, rate of feed, cutting depth, spindle speed, nomenclature of tool etc. To optimize the machining process, modelling and optimization of process variable of any industrialized process is usually a difficult work. The author [73] in-process input-output and parameter optimization techniques are divided into traditional optimization algorithms, nontraditional optimization algorithms. The traditional and nontraditional technique used for optimization is show in figure 5.

\section{The traditional optimization techniques are Modeling and Optimization Techniques}

Statistical Regression method and ANOVA, Fuzzy Set Theory - Artificial Neural Networks, Gray Relational Analysis (GRA), Taguchi Robust Design Method, Taguchi Fuzzy-Based Approach, Factorial Design Method, Response Surface Methodology, Knowledge-Based Expert Systems, Principal Component Analysis (PCA).

\section{Mathematical Iterative Search Methods:}

Dynamic Programming, Goal Programming, Generalized reduced gradient Method (GRG), Geometric Programming, Quadratic Programming, Integer Linear Programming [74], [75].

The nontraditional optimization algorithms are MetaHeuristics optimization techniques:

Genetic Algorithms, Simulated Annealing, Tabu Search, Particle Swarm Optimization, Ant Colony Optimization, Artificial Bee Colony Algorithm, Artificial Immune Algorithm, Shuffled Frog Leaping Algorithm, Harmony Search Algorithm. 
Hybrid Algorithms: Genetic Simulated annealing algorithm (GSA), Hybrid immune algorithm (artificial immune algorithm and hill climbing local search algorithm), Memetic algorithm (GA is combined with the heavy local search), Hybrid approach (GA, SA, and tabu search), Heuristic algorithms such as SA, GA and hybrid algorithm(hybrid-GASA), Novel hybrid ant colony optimization approach, Adaptive network based fuzzy inference system (ANFIS) with the genetic learning algorithm, Hybrid Taguchi-genetic learning algorithm (HTGLA), Multi-objective optimization method based on adaptive simulated annealing genetic algorithm, Hybrid global best harmony search (hgHS) algorithm and hybrid modified global best harmony search (hmgHS) algorithm, Hybrid meta-heuristics with evolutionary algorithms, Hybrid harmony search (hHS) algorithm Apart from the optimization the author added some the optimization techniques that are used while conducting literature survey in Duplex stainless steel.

Modeling and Optimization Techniques:

Dijkstra's optimization algorithm, MADM METHODS (Multiple Attribute Decision Making and Multiple Objective Decision Making).

Table 2. DSS Material used in Experimental Work

\begin{tabular}{|c|c|c|c|c|c|c|c|c|}
\hline $\begin{array}{l}\text { Generations } \\
\text { of DSS }\end{array}$ & $\begin{array}{c}\text { Grade/ } \\
\text { Commercial } \\
\text { Name- DSS } \\
\end{array}$ & $\begin{array}{c}\text { UNS } \\
\text { Number - } \\
\text { DSS } \\
\end{array}$ & $\begin{array}{l}\text { EN } \\
\text { Nr.- } \\
\text { DSS }\end{array}$ & Surface Roughness & Tool Wear & Machinability & MRR & $\begin{array}{c}\text { Chip } \\
\text { volume } \\
\text { ratio }\end{array}$ \\
\hline \multirow{3}{*}{$\begin{array}{c}\text { First generation } \\
\text { duplex stainless } \\
\text { steel }\end{array}$} & 329 & S32900 & 1.4460 & - & - & - & - & - \\
\hline & 3RE60 & S 31500 & 1.4424 & - & - & - & - & - \\
\hline & 324 & S32404 & - & - & - & - & - & - \\
\hline \multirow{10}{*}{\begin{tabular}{c|} 
Lean duplex \\
stainless steel
\end{tabular}} & A789 & S32001 & 1.4482 & - & - & - & - & - \\
\hline & LDX 2101 & S32101 & 1.4162 & - & 44 & & 72 & 72 \\
\hline & A815 & S32202 & 1.4062 & - & - & - & - & - \\
\hline & EDX 2304 & S32304 & 1.4362 & - & - & - & - & - \\
\hline & ATI 2102 & S82011 & - & - & - & - & - & - \\
\hline & FDX 25 & S82012 & 1.4635 & - & - & - & - & - \\
\hline & NSSC 2120 & S 82122 & - & - & - & - & - & - \\
\hline & A815 & S31803 & 1.4655 & -- & - & - & - & - \\
\hline & - & - & 1.4669 & - & - & - & - & - \\
\hline & $316 \mathrm{~L}$ & - & 1.4404 & 11,17 & 50 & 11 & - & - \\
\hline \multirow{5}{*}{$\begin{array}{c}\text { Molybdenum - } \\
\text { containing Lean } \\
\text { duplex stainless } \\
\text { steel }\end{array}$} & A790 & S32003 & - & - & - & - & - & - \\
\hline & A240 & S81921 & - & - & - & - & - & - \\
\hline & FDX 27 & S82031 & 1.4637 & - & - & - & - & - \\
\hline & A790 & S 82121 & - & - & - & - & - & - \\
\hline & LDX 2404 & S 82441 & 1.4662 & - & - & - & - & - \\
\hline \multirow{4}{*}{$\begin{array}{c}\text { Standard duplex } \\
\text { stainless steel }\end{array}$} & 2205 & S31803 & 1.4462 & - & - & - & - & - \\
\hline & 2205 & S32205 & 1.4462 & $\begin{array}{c}6,7,8,11,13,14,15,16,17 \\
19,21,23,26,27,29,30,31 \\
33,35,38,41,71\end{array}$ & $\begin{array}{c}15,23,29,30,41,42,43,44,47,48 \\
49,50,52,53,54,55,60\end{array}$ & $11,41,43,49,68,69$ & 71,72 & 72 \\
\hline & A473 & S32950 & - & - & - & - & - & - \\
\hline & DP28W & S32808 & - & - & - & - & - & - \\
\hline \multirow{7}{*}{$\begin{array}{l}\text { Super duplex } \\
\text { stainless steel }\end{array}$} & NAS 64 & S32506 & - & - & - & - & - & - \\
\hline & F255 & S 32520 & 1.4507 & - & - & - & - & - \\
\hline & 255 & S32550 & 1.4507 & - & - & - & & - \\
\hline & 2507 & S 32750 & 1.4410 & $\begin{array}{c}6,9,10,11,12,15,16,17,18 \\
20,22,24,25,28,32,3739,40\end{array}$ & $\begin{array}{c}12,15,24,25,32,37,39,44,46,50 \\
51,53,57,58,59,61,64\end{array}$ & 11,68 & $9,10,72$ & $9,10,72$ \\
\hline & F55 & S32760 & 1.4501 & 34,36 & & 34,36 & - & - \\
\hline & SAF 2906 & S32906 & 1.4477 & - & - & - & - & - \\
\hline & A790 & S39277 & - & - & - & - & - & - \\
\hline \multirow{2}{*}{$\begin{array}{l}\text { Hyper duplex } \\
\text { stainless steel }\end{array}$} & SAF $3707 \mathrm{HD}$ & S32707 & - & - & - & - & - & - \\
\hline & SAF $3207 \mathrm{HD}$ & S33207 & - & - & - & - & - & - \\
\hline
\end{tabular}

Table 3. Various factors and Optimization used in Experimental work

\begin{tabular}{|c|c|c|c|c|}
\hline Author & Material used \& Tools used & $\begin{array}{c}\text { Quantative insight (Input \& } \\
\text { Output Responses) }\end{array}$ & $\begin{array}{l}\text { Optimization } \\
\text { Methods used }\end{array}$ & Outcomes \& Critical evaluation \\
\hline $\begin{array}{l}\text { Philip and } \\
\text { Chandramohan } \\
(2013)[6]\end{array}$ & $\begin{array}{l}\text { Material: ASTMGradeA-995, } \\
\text { ASTMGrade-4A and ASTM Grade } \\
\text { A-995 ASTMGrade-5A } \\
\text { Tools: TiCN Coated and TiC } \\
\text { Coated Cemented Carbide }\end{array}$ & $\begin{array}{l}\text { Input- } \mathrm{V}_{\mathrm{c}}(80,100,120,140 \\
\text { and } 160 \mathrm{~m} / \mathrm{min}), \mathrm{a}_{\mathrm{p}}(0.04,0.08 \text { and } \\
0.12 \mathrm{~mm} / \mathrm{rev}) \text {, Constant } \mathrm{f}_{\mathrm{z}}(0.5 \mathrm{~mm} / \mathrm{rev}) \\
\text { Output - Surface Roughness }\end{array}$ & $\begin{array}{l}\text { Statistical regression } \\
\text { technique, Texture } \\
\text { analysis(Bulk) }\end{array}$ & $\begin{array}{l}\text { ASTM A } 995 \text { Grade5A leads to better surface } \\
\text { finish. Texture analysis only carried out, recent } \\
\text { optimization methods are not used for prediction. }\end{array}$ \\
\hline $\begin{array}{l}\text { Krolczyk et al. } \\
\text { (2013) [7] }\end{array}$ & $\begin{array}{l}\text { Material: } 1.4462 \text { (DIN EN 10088- } \\
\text { 1) DSS \& } \\
\text { Tools: Duplex coated carbide tools } \\
\text { (T1 MM 2025) (T2 CTC } 1135 \text { ) }\end{array}$ & $\begin{array}{l}\text { Input- Vc }(50,100,150 \mathrm{~m} / \mathrm{min}), \mathrm{a}_{\mathrm{p}}(2 \mathrm{~mm}) \\
\mathrm{f}_{\mathrm{z}}(0.3 \mathrm{~mm} / \mathrm{rev}) \\
\text { Output - Surface Roughness }\end{array}$ & $\begin{array}{l}\text { Statistical regression } \\
\text { technique }\end{array}$ & $\begin{array}{l}\text { Increase of } \mathrm{Vc} \text { (from } 50 \mathrm{~m} / \mathrm{min} \text { to } 150 \mathrm{~m} / \mathrm{min} \text { ) tends } \\
\text { to increase of surface hardness. Work is done to } \\
\text { perform the hardness using different grade of tools }\end{array}$ \\
\hline $\begin{array}{l}\text { Krolczyk et al. } \\
{[8]}\end{array}$ & 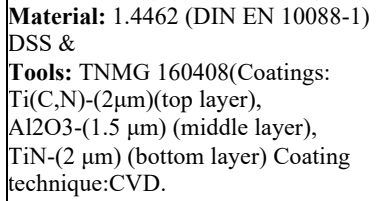 & $\begin{array}{l}\text { Input- Vc }(50 \text { and } 150 \mathrm{~m} / \mathrm{min}), \mathrm{a}_{\mathrm{p}}(2 \mathrm{~mm}), \mathrm{f}_{\mathrm{z}} \\
\text { (0.2and } 0.4 \mathrm{~mm}) \\
\text { Output - Surface Roughness }\end{array}$ & $\begin{array}{l}\text { Statistical regression } \\
\text { technique }\end{array}$ & $\begin{array}{l}\mathrm{f}_{z} \text { was main factor influences surface roughness. } \\
\text { The ranges is not specified by author to get } \\
\text { optimum cutting conditions }\end{array}$ \\
\hline $\begin{array}{l}\text { Senthil Kumar } \\
\text { et al. (2013) [9] }\end{array}$ & $\begin{array}{l}\text { Material: SAF } 2507 \text { DSS } \\
\text { Tools: Uncoated cemented carbide } \\
\text { cutting tool inserts - CNMG 120408- } \\
\text { QM, grade H13A }\end{array}$ & $\begin{array}{l}\text { Input- } \mathrm{Vc}(100 \mathrm{and} 120 \mathrm{~m} / \mathrm{min}), \mathrm{f}_{\mathrm{z}}(0.6,0.8 \\
\text { and } 1.00 \mathrm{~mm} / \mathrm{rev}), \quad \mathrm{a}_{\mathrm{p}}(0.5,0.75 \text { and } \\
1.00 \mathrm{~mm}) \\
\text { Output - Surface Roughness and } \mathrm{S} / \mathrm{N} \text { ratio }\end{array}$ & $\begin{array}{l}\text { ANOVA and Taguchi } \\
\text { method }\end{array}$ & $\begin{array}{l}\mathrm{Vc}-100 \mathrm{~m} / \mathrm{min}, \mathrm{f}_{\mathrm{z}}-0.06 \mathrm{~mm} / \mathrm{rev} \text {, and Depth of cut } \\
0.75 \mathrm{~mm} \text {. Feed rate was main factor influences on } \\
\text { surface roughness }\end{array}$ \\
\hline $\begin{array}{l}\text { Senthil Kumar } \\
\text { and } \\
\text { SenthilKumaar } \\
\text { (2014) [10] }\end{array}$ & $\begin{array}{l}\text { Material: SAF } 2507 \text { DSS } \\
\text { Tools: Uncoated cemented carbide } \\
\text { cutting tool inserts - CNMG } 120408 \text { - } \\
\text { QM, grade H13A }\end{array}$ & $\begin{array}{l}\text { Input- Vc }(80,100 \text { and } 120 \mathrm{~m} / \mathrm{min}), \mathrm{f}_{\mathrm{z}} \\
(0.6,0.8 \mathrm{and} 1.00 \mathrm{~mm}), \quad \mathrm{a}_{\mathrm{p}}(0.5,0.75 \text { and } \\
1.00 \mathrm{~mm}) \\
\text { Output - Surface Roughness and Flank } \\
\text { wear }\end{array}$ & $\begin{array}{l}\text { ANOVA and Taguchi } \\
\text { method }\end{array}$ & $\begin{array}{l}\text { Using liquid } \mathrm{CO}_{2} \text { as coolant the surface roughness } \\
\text { and the flank wear was reduced. }\end{array}$ \\
\hline Rastee et al. & Material: EN 1.4404 austenitic, EN & Input- Vc $(50,100,150,200), a_{p}$ & Taguchi method, & The ANOVA result emphasizes that feed flow is \\
\hline
\end{tabular}


(2014) [11] $\quad$ 1.4462 Std DSS and EN 1.4410 SDSS $(0.5,1.5,2.5,3.5), f_{z}(0.1,0.25,0.4,0.55)$ Tools: Coated carbide inserts CNMG 120408-MM 2025

De Oliveira Material: Super duplex stainless steel Input- Vc (110and $130 \mathrm{~m} / \mathrm{min}), \mathrm{f}_{\mathrm{z}}$ Junior et al. (2014) [12]

UNS S32750 Tools: Cemented $(0.15 \mathrm{~mm} / \mathrm{rev}), \mathrm{a}_{\mathrm{p}}(1 \mathrm{~mm})$, low and high carbide grade - ISO M25 grade PVD fluid pressure cooling conditions multi-coated with TiAlN and TiN Output - Surface Roughness, Tool wear, layers Corrosion resistance

Krolczyk and Material: 1.4462 (DIN EN 10088-1) Input- Vc (50-150m/min), $a_{p}(1-3 \mathrm{~mm}), \mathrm{f}_{\mathrm{z}}$ Legutko (2014) Tools: Cutting tool inserts - TNMG $(0.2-0.4 \mathrm{~mm} / \mathrm{rev})$

[13] $\begin{array}{ll}160408 & \text { Output - Surface Roughness, Tool wear }\end{array}$

Thiyagu and Arunkumar (2014) [14]

Material: UNS 31803 (2205) DSS \& 1115 Sandvik Coromant 120408 SM grade PVD muli-layeromant make with PVD multi-layer coating (TiAlN + Chromium Oxide)

Philip et al (2014) [15]

Material: Cast DSS ASTM A 995 grade $5 \mathrm{~A}$ and grade $4 \mathrm{~A}$

Tools: $\mathrm{TiC}$ and $\mathrm{TiCN}$ coated carbide cutting tool

$(0.4,0.8,1.2 \mathrm{~mm} / \mathrm{rev}), a_{p}(0.051,0.128,0.205$

$\mathrm{mm})$, Nose radius $(0.4,0.8,1.2)$

Output - Surface Roughness and Cutting force

Input- Vc $(80,100,120 \mathrm{~m} / \mathrm{min}), \mathrm{a}_{\mathrm{p}}$ $(0.5 \mathrm{~mm}), \mathrm{f}_{\mathrm{z}}(0.04,0.08$ and $0.12 \mathrm{~mm} / \mathrm{rev})$

Output - Surface Roughness and Cutting force

Koyee et al Material: Standard duplex EN 1.4462 Input- Vc-200 m/min, $\mathrm{a}_{\mathrm{p}}-1.5 \mathrm{~mm}, \mathrm{f}_{\mathrm{z}}-0.25$ (2014) [16]

and super duplex EN 1.4410 stainless $\mathrm{mm} / \mathrm{rev}$,Length of cut $-12 \mathrm{~mm}$ process steel rods Tools: Coated condition

carbide inserts with ISO code of CNMG120408-QM 2025

Output - Surface Roughness, radial cutting force, effective cutting power, maximum tool flank wear and chip volum ratio

Ali. 2015 [17] Material: Austenitic EN 1.4404, Input- Vc- $(100,180 \mathrm{~m} / \mathrm{min}), \mathrm{a}_{\mathrm{p}}(1 \mathrm{~mm}), \mathrm{f}$ standard duplex EN 1.4462 and super $(0.15,0.2,0.25,0.3,0.35,0.4 \mathrm{~mm} / \mathrm{rev})$, duplex EN 1.4410 Tools: Cooling medium - Dry, Wet Coated carbide inserts - CNMG Output - Cutting Power, Surface 120408-MM 2025 and CNMG Roughness, Chip volume ratio, Tool wear, 120408-QM 2025. Roughness,

Ramadhan et al. Material: Super duplex stainless steel Input- Vc $\left(12.5,22.5 \mathrm{~m} / \mathrm{min}, \mathrm{a}_{\mathrm{p}}(0.25 \mathrm{~mm})\right.$, (2015) [18] SAF 2507 Tools: TiC insert $\mathrm{f}_{\mathrm{z}}(0.06,0.08,0.1,0.12$ and $0.14 \mathrm{~mm} / \mathrm{rev})$ Output - Surface roughness

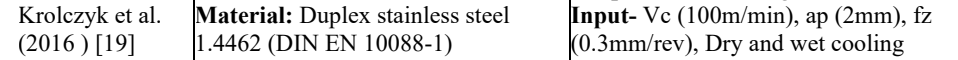
Tools: TNMG 160408 conditions

Output - Surface roughness, Tool wear

Rohit et al (2016) [20]

Material: SAF2507 DSS \& Input- $\mathrm{Vc}(60-360 \mathrm{~m} / \mathrm{min})$, ap $(0.5-2 \mathrm{~mm})$ Tools: PVD coated carbide inserts - fz $(0.05-0.35 \mathrm{~mm} / \mathrm{rev})$ TiAlSiN, AlTiN $(3 \mu \mathrm{m})$ and AlTiN (7 Output - Surface Roughness, $\mu \mathrm{m})$ machinability cutting force, tool wear Krolczyk et al Material: 1.4462 (DIN EN 10088-1) Input- Vc (50m/min), fz (0.05mm/rev)

DSS Tools: Coated carbide inserts with ISO code of TNMG 160408 - GC 2025

Mario and Jozić Material: EN 1.4410 (2017) [22] Tools: TiC insert

Liew et al. (2017) Material: 2205 DSS \& [23] $\quad$ Tools: TiAlN coated carbide

Kadam et al. Material: Super DSS -2507 (2017) [24] Tools: TiAlSiN PVD coated tool $(3.3 \mu \mathrm{m}), \operatorname{AlTiN}(3 \mu \mathrm{m})$ and $\operatorname{AlTiN}(7 \mu \mathrm{m})$.

Gamarra et al. Material: Super duplex stainless Input- Vc $(150 \mathrm{~m} / \mathrm{min}), \mathrm{Ap}(0.5 \mathrm{~mm})$, Tool (2018) [25] steel-SAF 2507 Tools: Carbide geometries, coolan inserts - CNMG120408MM-GC 1115 Output - Surface Roughness, Tool wear and index able wiper inserts

CNMG120408WF-GC 1115

Pawan and

Material: DSS (2205) Misra (2018) Tools: WC-Co cutting inserts, TNMG $(0.05,0.20,0.36 \mathrm{~mm} / \mathrm{rev})$ and approach [26] 160404 FM TN8135

Philip. (2018) Material: ASTM A 995 Grade 5A [27] Tools: Carbide inserts coated with $\mathrm{TiC}$ and TiCN with a specification of SNMG 120408 MT TT5100 Auteur Mario Material: EN 1.4410 super DSS Veić et al. (2018) Tools: C5-CSRNR/L-27060-12-4 [28] Tools: C5-CSRNR/L-2706 al. (2018) [29] Tools: PVD coated Nano-multilayer TiAlN cutting tool insert

Material: AISI 2205 DSS Tools: Multi-layer coated carbide insert (TiN/A12O3/TICN/TiN)

Material: Duplex 2205 (2019) [31] Tools: Tungsten carbide

Subhash et al. Material: SDSS SAF 2507
Input- $\mathrm{Vc}(550,930,1210 \mathrm{~m} / \mathrm{min}), \mathrm{fz}$

Input- Vc, fz, ap

Output - Machinability, Surface roughness

Input- Vc $(210 \mathrm{~m} / \mathrm{min}), \mathrm{fz}(0.10 \mathrm{~mm} / \mathrm{rev})$, ap $(1.00 \mathrm{~mm})$

Input- $\mathrm{Vc}(60-360 \mathrm{~m} / \mathrm{min}), \mathrm{fz}(0.05-$ $0.35 \mathrm{~mm} / \mathrm{rev})$ and ap $(0.5-2 \mathrm{~mm})$
Output - Surface Roughness, Tool wear angle $(60,75,90 \mathrm{~mm})$

Output - Surface Roughness

Input- $\mathrm{Vc}(80,100,120 \mathrm{~m} / \mathrm{min}), \mathrm{fz}$

$(0.04,0.08,0.12 \mathrm{~mm} / \mathrm{rev}), \quad$ Ap $(0.4$

$0.8,1.2 \mathrm{~mm})$

Output -Surface Roughness

Input- $\mathrm{Vc}(0.063,0.063 \mathrm{~m} / \mathrm{min}), \mathrm{fz}$

$(28,45$ and ap $(1,2 \mathrm{~mm})$

Output - Surface Roughness Input- Vc $(72,119,197 \mathrm{~m} / \mathrm{min}), \mathrm{fz}$

$(0.111 \mathrm{~mm} / \mathrm{rev})$, ap $(1 \mathrm{~mm})$,cryogenic cooling

Output -Surface Roughness, Tool wear, machinability

Input- $\mathrm{Vc}(100,150,200 \mathrm{~m} / \mathrm{min}), \mathrm{fz}(0.1$, $0.2,0.3 \mathrm{~mm} / \mathrm{rev})$, ap $(0.4,0.8,1.2 \mathrm{~mm})$, cutting fluid. Output - Surface roughness, Tool wear and Tool temperature

Input- Spindle speed, fz and ap Output - M.R.R, surface roughness, feed force, thrust force and Cutting force Input- Vc $(40,60,80,100$, and Output - Surface Roughness, Tool wea
MADM, AHP-TOPSIS the most important factor affecting surface FMADM quality. The machining of austenitic stainles steel EN 1.4404 was considered easier to machine.

SEM analysis with Cooling pressure and cutting speed and their effect on tool life, roughness of part surface. PVD-coated inserts results long tool life

SRT, Surface texture The $\mathrm{f}_{\mathrm{z}}$ is the main parameter which affects the analysis- IFM method surface roughness.

\begin{tabular}{l|l} 
ANOVA, RSM & $\mathrm{f}_{\mathrm{z}}$ and $\mathrm{Vc}$ were the main parameter which
\end{tabular} affects the surface roughness.

TRDM, ANOVA signal The $\mathrm{f}_{\mathrm{z}}$ is the main parameter which affects the to noise ratio surface roughness. The $\mathrm{Vc}$ was the influencing the tool wear.

ANOVA, RSM, AHP- Vc and $f_{z}$ is the most influencing parameters TOPSIS, CSNNS

\section{SRT, Fuzzy Set}

Theory, GRA, RSM, AHP-TOPSIS, FANNS

The $f_{z}$ is the main parameter which affects the urface roughness.

omparison between heat, non-heat treated DSS material

Comparison between dry and wet cooling conditions

Comparison between tools

Dry and MQCL cutting technology quality.

ANOVA, RSM, GA. The $\mathrm{f}_{\mathrm{z}}$ is the main parameter which affects the surface roughness.

Comparison between dry and wet cooling

conditions

The surface roughness is low when the temperature of chilled air coolant decreases.

The tool wear is lower when using conventional coolant method.

Comparison between Higher Vc the temperature of the Continuous tools chips effects the machined surface and the hips effects the machined surface and
ncrease of the Vc effect the tool wear.

Comparison between ools

For long tool life and low surface roughness the $f_{z}$ value should be maintain very less

ANOVA, TRDM

$f_{z}$ is the most influential parameter reduces surface roughness

ANOVA, TRDM

$\mathrm{f}_{\mathrm{z}}$ is the most influential parameter reduces surface roughness

ANOVA, RSM, ANFIS $\mathrm{f}_{\mathrm{z}}$ is the most influential parameter reduces surface roughness

Dry and Wet Cooling liquid nitrogen decreased the Surface Roughness, conditions $\quad$ Tool wear, machinability

TRDM

Lower tool wear is observed at low Vc and high $\mathrm{f}_{z}$ and by using mineral oil to improving machinability

High Surface roughness is attained when spindle speed and DOC is high and high spindle speed the MRR is high

ANOVA, RSM, $\quad f_{z}$ is the most significant parameter which effects 


\begin{tabular}{|c|c|c|c|c|}
\hline (2019) [32] & $\begin{array}{l}\text { Tools: Carbide tool insert of ISO } \\
\text { CNMG 120408TF IC6015 }\end{array}$ & $\left|\begin{array}{l}120 \mathrm{~m} / \mathrm{min}), \quad \mathrm{fz}(0.05,0.1 \text {, and } \\
0.15 \mathrm{~mm} / \mathrm{rev}) \text { and ap }(0.5 \mathrm{~mm}) \text {, dry and wet } \\
\text { machining } \\
\text { Output - Temperature, Surface Roughness }\end{array}\right|$ & ANN,GA & $\begin{array}{l}\text { on surface finish, Tool flank wear is observed } \\
\text { more in dry cutting condition, and increased with } \\
\text { increasing Vc. }\end{array}$ \\
\hline Sonawane and & Material: DSS 2205 & Input- Vc $(100,40,180 \mathrm{~m} / \mathrm{min})$, constant $\mathrm{fz}$ & RSM, PVD High Pulse & Increase in Vc, results better surface roughness \\
\hline $\begin{array}{l}\text { Sargade (2019) } \\
{[33]}\end{array}$ & $\begin{array}{l}\text { Tools: AlTiCrN and AlTiN with } 4 \mu \mathrm{m} \\
\text { thickness }\end{array}$ & $\begin{array}{l}(0.18 \mathrm{~mm} / \mathrm{rev}) \text { and ap }(0.8 \mathrm{~mm}) \\
\text { Output }- \text { Surface Roughness, Cutting } \\
\text { Temperatures, Compressive Residual } \\
\text { Stresses }\end{array}$ & $\begin{array}{l}\text { Impulse Magnetron } \\
\text { Sputtering (HiPIMS) } \\
\text { technique. }\end{array}$ & \\
\hline $\begin{array}{l}\text { Dinde and } \\
\text { Dhende } \\
(2020)[34]\end{array}$ & $\begin{array}{l}\text { Material: Super-DSS UNS S32760 } \\
\text { Tools: Nano-coated MEGACOAT } \\
\text { carbide inserts }\end{array}$ & $\begin{array}{l}\text { Input- Vc }(110,120,130 \mathrm{~m} / \mathrm{min}), \mathrm{fz}(0.20, \\
0.22,0.25 \mathrm{~mm} / \mathrm{rev}) \text { and ap }(1.8,2.0,2.3 \mathrm{~mm}) \\
\text { Output - Cutting force, Surface roughness, } \\
\text { MRR }\end{array}$ & ANOVA,TRDM, GRA & $\begin{array}{l}\text { Optimal cutting conditions are to minimum surface } \\
\text { roughness are } \mathrm{Vc}=120 \mathrm{~m} / \mathrm{min}, \mathrm{fz}=0.20 \mathrm{~mm} / \mathrm{rev} \text {, } \\
\mathrm{ap}=2.0 \mathrm{~mm} \text { and For MRR is optimum value is } \\
\text { attained at } 48 \mathrm{cc} / \mathrm{min}\end{array}$ \\
\hline $\begin{array}{l}\text { Kumar and } \\
(2020)[35]\end{array}$ & $\begin{array}{l}\text { Material: DSS } 2205 \& \\
\text { Tools: WC-Co coated carbide inserts }\end{array}$ & $\begin{array}{l}\text { Input- Vc }(43.18,73.0,94.99 \mathrm{~m} / \mathrm{min}), \mathrm{fz} \\
(0.05,0.20,0.36 \mathrm{~mm} / \mathrm{rev}), \text { approach } \\
\text { angle }(60,75.90 \mathrm{degree}) \\
\text { Output - Surface roughness, MRR }\end{array}$ & ANOVA, TRDM & $\begin{array}{l}\text { Feed rate is most influencing factor affecting each } \\
\text { machining characteristics }\end{array}$ \\
\hline $\begin{array}{l}\text { Dinde and } \\
\text { Dhende (2020) } \\
{[36]}\end{array}$ & $\begin{array}{l}\text { Material: Super-DSS UNS S32760 } \\
\text { Tools: Nano-coated MEGACOAT } \\
\text { carbide insert }\end{array}$ & $\begin{array}{l}\text { Input- } \mathrm{Vc}(110,120,130 \mathrm{~m} / \mathrm{min}), \mathrm{fz}(0.20, \\
0.22,0.25 \mathrm{~mm} / \mathrm{rev}) \text { and ap }(1.8,2.0, \\
2.3 \mathrm{~mm}) \\
\text { Output - Surface roughness, Cutting } \\
\text { force, and MRR }\end{array}$ & $\begin{array}{l}\text { ANOVA, TRDM, S/N } \\
\text { ratio analysis }\end{array}$ & $\begin{array}{l}\text { For Least surface roughness the } \mathrm{Vc}: 120 \mathrm{~m} / \mathrm{min} \text {, } \\
\mathrm{f}_{\mathrm{z}}: 0.20 \mathrm{~mm} / \mathrm{rev} \text {, depth of cut } 2.0 \mathrm{~mm} \text { should be } \\
\text { maintained., highest MRR is attained at } \mathrm{Vc}=130 \\
\mathrm{~m} / \mathrm{min}, \mathrm{f}_{\mathrm{z}}=0.25 \mathrm{~mm} / \mathrm{rev} \text {, and ap }=2.3 \mathrm{~mm}\end{array}$ \\
\hline $\begin{array}{l}\text { Narayanan et al. } \\
(2020)[37]\end{array}$ & $\begin{array}{l}\text { Material: Super DSS }-2507 \\
\text { Tools: PVD-coated tungsten carbide } \\
\text { inserts (CNMG 120408MT12) }\end{array}$ & $\begin{array}{l}\text { Input- Constant } \mathrm{Vc}(113 \mathrm{~m} / \mathrm{min}), \mathrm{fz} \\
(0.35,0.26,0.21 \mathrm{~mm} / \mathrm{rev}), \quad \text { ap }(1.2, \\
1.6,2.0 \mathrm{~mm})\end{array}$ & $\begin{array}{l}\text { Dry machining, } \\
\text { Cryogenic machining }\end{array}$ & $\begin{array}{l}\mathrm{f}_{\mathrm{z}} \text { has more influencing parameter that affect } \\
\text { surface roughness and tool life }\end{array}$ \\
\hline $\begin{array}{l}\text { Mavi. (2020) } \\
\text { [38]. }\end{array}$ & $\begin{array}{l}\text { Material: DSS }-2205 \\
\text { Tools: TiN and TiAlN coated carbide } \\
\text { drills }\end{array}$ & $\begin{array}{l}\text { Output - Surface roughness, MRR } \\
\text { Input- Vc }(15,20,25 \mathrm{~m} / \mathrm{min}), \text { fz }(0.05, \\
0.75,0.1 \mathrm{~mm} / \mathrm{rev}), \text { Cutting tool types } \\
\text { Output - Cutting force (Fc) and surface } \\
\text { roughness (Ra) }\end{array}$ & $\begin{array}{l}\text { Gray relational } \\
\text { analysis,, ANOVA }\end{array}$ & $\begin{array}{l}\mathrm{f}_{\mathrm{z}} \text { most significant factor that affect surface } \\
\text { roughness }\end{array}$ \\
\hline $\begin{array}{l}\text { Rajaguru and } \\
\text { Arunachalam } \\
(2020)[39]\end{array}$ & $\begin{array}{l}\text { Material: Super DSS }-2507 \& \\
\text { Tools: Tungsten carbide inserts } \\
\text { (KCM15) }\end{array}$ & $\begin{array}{l}\text { Input- Dry, Flood, MQL, Vc }(140 \mathrm{~m} / \mathrm{min}) \\
\text { ap }(1 \mathrm{~mm}) \text {, Five different fz }(0.05,0.10, \\
0.15,0.20 \text { and } 0.25 \mathrm{~mm} / \mathrm{rev}) \\
\text { Output - Tool wear, cutting force, surface } \\
\text { Roughness, morphology of chips and } \\
\text { residual stress }\end{array}$ & SEM Analysis & $\begin{array}{l}\text { Poor surface finish is obtained at dry cutting } \\
\text { conditions, Machining under flood } \\
\text { and MQL reduces tool wear and Machinability. }\end{array}$ \\
\hline $\begin{array}{l}\text { Subhash et al. } \\
(2020)[40]\end{array}$ & $\begin{array}{l}\text { Material: Hot forged SDSS } 2507 \\
\text { (ASTM A240 - UNS S32750) } \\
\text { Tools: CCMT120408MR type with a } \\
\text { grade of GC2220 }\end{array}$ & $\begin{array}{l}\text { Input- Vc }(160,175,190,205 \mathrm{~m} / \mathrm{min}), \mathrm{fz} \\
(0.15 ; 0.175 ; 0.2 ; 0.225 \mathrm{~mm} / \mathrm{rev}) \text { and ap } \\
(1.5 \mathrm{~mm}) \\
\text { Output - Cutting forces, Surface } \\
\text { roughness }\end{array}$ & $\begin{array}{l}\text { Frequency response } \\
\text { functions (FRFs) }\end{array}$ & $\begin{array}{l}\text { The optimal speed reduces the surface roughness } \\
\text { and increases Machinability }\end{array}$ \\
\hline $\begin{array}{l}\text { Sonawane and } \\
\text { Sargade }(2020) \\
\text { [41] }\end{array}$ & $\begin{array}{l}\text { Material: DSS2205 } \\
\text { Tools: M35 grade Indexable Carbide } \\
\text { tool - CNMG120408 }\end{array}$ & $\begin{array}{l}\text { Input- } \mathrm{Vc}(100,140 \text { and } 180 \mathrm{~m} / \mathrm{min}), \mathrm{fz} \\
(0.12,0.15,0.18 \mathrm{~mm} / \mathrm{rev}) \text { and constant ap } \\
(0.8 \mathrm{~mm}) \quad \text { Output - Tool } \\
\text { wear, Surface Roughness, Machinability }\end{array}$ & $\begin{array}{l}\text { Regression Analysis, } \\
\text { High Power Impulse } \\
\text { Magnetron Sputtering } \\
\text { technique, }\end{array}$ & $\begin{array}{l}\text { Combination of high } \mathrm{Vc}(180 \mathrm{~m} / \mathrm{min}) \text { and low } \mathrm{f}_{\mathrm{z}} \\
(0.12 \mathrm{~mm} / \mathrm{rev}) \text { resulted in least surface finish. } \\
\text { AlTiCrN and AlTiN coated tools show } \\
\text { respectively 6-times more tool life than uncoated } \\
\text { tools }\end{array}$ \\
\hline $\begin{array}{l}\text { Jiang et al. } \\
(1996)[42]\end{array}$ & $\begin{array}{l}\text { Material: HIP austenitic steel (PM } \\
\text { 316L), HIP DSS (PM 2205) } \\
\text { Tools: TiN - coated cemented } \\
\text { Carbide }\end{array}$ & $\begin{array}{l}\text { Input- Vc }(15,35,45,55 \mathrm{~m} / \mathrm{min}), \mathrm{fz}(0.15 \\
\mathrm{mm} / \mathrm{rev}) \text { and constant ap }(1.0 \mathrm{~mm}) \\
\text { Output - Cutting force, surface } \\
\text { Roughness, Tool wear }\end{array}$ & SEM and EDS analysis & $\begin{array}{l}\text { Vc should be below } 35 \mathrm{~m} / \mathrm{min} \text { to achieve less tool } \\
\text { wear }\end{array}$ \\
\hline $\begin{array}{l}\text { Bouchnak et } \\
\text { al.(2010) [43] }\end{array}$ & $\begin{array}{l}\text { Material: Duplex stainless steel, } \\
\text { X2CrNiMo22-5 } \\
\text { Tools: HPWJAT tool }\end{array}$ & $\begin{array}{l}\text { Input- Vc }\left(350,450 \mathrm{~m} \cdot \mathrm{min}^{-1}\right) \text {, fz }(0.15 \\
\text { mm.tr-1 }) \text {, ap }(0.5 \mathrm{~mm}) \\
\text { Output - Surface Roughness, Tool wear }\end{array}$ & $\begin{array}{l}\text { High pressure water jet } \\
\text { assisted turning } \\
\text { (HPWJAT) }\end{array}$ & $\begin{array}{l}\text { The improvement of tool life by using high } \\
\text { pressure water jet assistance }\end{array}$ \\
\hline $\begin{array}{l}\text { Schultheiss et } \\
\text { al.(2011) [44] }\end{array}$ & $\begin{array}{l}\text { Material: SAF 2507, SAF } 2205 \text { and } \\
\text { LDX 2101 } \\
\text { Tools: Coated carbide tools }\end{array}$ & $\begin{array}{l}\text { Input- Vc, fz, ap } \\
\text { Output - Tool wear }\end{array}$ & ANOVA & $\mathrm{f}_{\mathrm{z}}$ is the most influencing parameter - tool wear \\
\hline $\begin{array}{l}\text { Ahmadi et al. } \\
\text { (2012) [45] }\end{array}$ & $\begin{array}{l}\text { Material: Austenitic ferritic } \\
\text { (Duplex) stainless steel ( } 330 \mathrm{HRC}) \\
\text { Tools: Ceramic cutting tool with } \\
\text { Alumina base (aluminium oxide) }\end{array}$ & $\begin{array}{l}\text { Input- Vc }(120,170, \\
220 \text { and } 270 \mathrm{~m} / \mathrm{min}), \mathrm{fz}(0.12 \mathrm{~mm} / \mathrm{rev}) \text {, ap } \\
(0.5 \mathrm{~mm}) \\
\text { Output - Tool wear }\end{array}$ & $\begin{array}{l}\text { Multi-regression } \\
\text { analysis (MRA), } \\
\text { (ANOVA). }\end{array}$ & $\begin{array}{l}\text { Alumina-based ceramic cutting tools the flank } \\
\text { wear has a considerable effect }\end{array}$ \\
\hline $\begin{array}{l}\text { Kumar and } \\
\text { Senthilkumaar } \\
\text { (2013) [46] }\end{array}$ & $\begin{array}{l}\text { Material: Super DSS - SAF } 2507 \\
\text { Tools: Uncoated Cemented carbide } \\
\text { cutting tool inserts(CNMG } 120408- \\
\text { QM, grade H13A) }\end{array}$ & $\begin{array}{l}\text { Input- Vc }(100,120 \mathrm{~m} / \mathrm{min}), \mathrm{fz} \\
(0.06,0.08,1.0 \mathrm{~mm} / \mathrm{rev}), \text { ap }(0.5,0.75,1 \mathrm{~mm}) \\
\text { Output - Tool wear }\end{array}$ & $\begin{array}{l}\text { Regression analysis, } \\
\text { TRDM, SEM analysis }\end{array}$ & Tool wear is low in gas cooled machining \\
\hline $\begin{array}{l}\text { Królczyk et al. } \\
\text { (2013) [47] }\end{array}$ & $\begin{array}{l}\text { Material: } 1.4462 \text { (DIN EN 10088-1) } \\
\text { steel } \\
\text { Tools: Cutting tool inserts of TNMG } \\
160408\end{array}$ & $\begin{array}{l}\text { Input- Vc }(50,150 \mathrm{~m} / \mathrm{min}), \mathrm{fz}(0.3 \mathrm{~mm} / \mathrm{rev}) \\
\text { ap }(2 \mathrm{~mm}) \\
\text { Output - Tool wear }\end{array}$ & SEM analysis & Wear of tool is due to Increase of the Vc \\
\hline $\begin{array}{l}\text { Królczyk et } \\
\text { al.(2013b) [48] }\end{array}$ & $\begin{array}{l}\text { Material: } 1.4462 \text { (DIN EN 10088-1) } \\
\text { steel } \\
\text { Tools: Cutting tool inserts of TNMG } \\
160408\end{array}$ & $\begin{array}{l}\text { Input- } \mathrm{Vc}(50,150 \mathrm{~m} / \mathrm{min}), \mathrm{fz} \\
(0,2,0,4 \mathrm{~mm} / \mathrm{rev}), \text { ap }(1,3 \mathrm{~mm}) \\
\text { Output - Tool wear, surface Roughness }\end{array}$ & $\begin{array}{l}\text { Factorial Design } \\
\text { Method, } \\
\text { Metallographic } \\
\text { microscopy analysis }\end{array}$ & $\begin{array}{l}\text { Wear of tool is due to Increase of the Vc. The } \\
\text { CVD - Ti(C, N)/A12O3/TiN coated carbide tools } \\
\text { has greater resistance to abrasive wear }\end{array}$ \\
\hline $\begin{array}{l}\text { Krolczyk et } \\
\text { al. }(2013 \text { c) [49] }\end{array}$ & $\begin{array}{l}\text { Material: } 1.4462 \text { (DIN EN 10088-1) } \\
\text { steel } \\
\text { Tools: Cutting tool inserts of TNMG } \\
160408\end{array}$ & $\begin{array}{l}\text { Input- Vc }(50,150 \mathrm{~m} / \mathrm{min}), \mathrm{fz}(0,2,0,4 \\
\mathrm{mm} / \mathrm{rev}), \text { ap }(1,3 \mathrm{~mm}) \\
\text { Output - Tool wear }\end{array}$ & $\begin{array}{l}\text { Factorial Design } \\
\text { Method }\end{array}$ & Wear of tool is due to Increase of the Vc \\
\hline $\begin{array}{l}\text { Rastee et al. } \\
(2013)[50]\end{array}$ & $\begin{array}{l}\text { Material: Super DSS EN } 1.4410, \\
\text { standard DSS EN } 1.4462 \text { and } \\
\text { austenitic EN, 1.4404 stainless steels } \\
\text { Tools: Coated carbide inserts (CNMG } \\
\text { 120408-MM 2025) }\end{array}$ & $\begin{array}{l}\text { Input- fz }(0.1,0.175,0.25,0.325, \\
0.4 \mathrm{~mm} / \mathrm{rev}) \text {, ap }(0.5,1,1.5,2,2.5,3, \\
3.5 \mathrm{~mm}) \\
\text { Output - Tool wear }\end{array}$ & $\begin{array}{l}\text { TOPSIS, GRA, VIKOR } \\
\text { method, Utility } \\
\text { Analysis (UA), } \\
\text { MADM, MOO }\end{array}$ & Dominant at lower $\mathrm{f}_{\mathrm{z}}$ the tool wear is high \\
\hline $\begin{array}{l}\text { Kumar et al. } \\
(2014)[51]\end{array}$ & $\begin{array}{l}\text { Material: Super DSS SAF } 2507 \\
\text { Tools: Uncoated cemented carbide } \\
\text { cutting tool inserts(CNMG 120408- } \\
\text { QM, grade H13A) }\end{array}$ & $\begin{array}{l}\text { Input- Vc }(100,120 \mathrm{~m} / \mathrm{min}), \mathrm{fz}(0.06,0.08, \\
0.10 \mathrm{~mm} / \mathrm{rev}), \quad \text { ap }(0.50,0.751 .0 \mathrm{~mm}) \\
\text { Output - Tool wear }\end{array}$ & $\begin{array}{l}\text { Dry, wet, gas cooled } \\
\text { Machining, SEM } \\
\text { analysis }\end{array}$ & Gas cooled machining increases tool life \\
\hline $\begin{array}{l}\text { Krolczyk et al. } \\
(2015)[52]\end{array}$ & $\begin{array}{l}\text { Material: Duplex stainless steel } \\
1.4462 \text { (DIN EN } 10088-1 \text { ) } \\
\text { Tools: Cutting tool inserts of TNMG } \\
160408\end{array}$ & $\begin{array}{l}\text { Input- } \mathrm{Vc}(50,100,150 \mathrm{~m} / \mathrm{min}, \mathrm{fz} \\
(0.2,0.3,0.4 \mathrm{~mm} / \mathrm{rev}, \mathrm{ap}(1,2,3 \mathrm{~mm}) \\
\text { Output - Tool wear }\end{array}$ & \begin{tabular}{|} 
Factorial Design \\
Method, Dry and Wet \\
cutting condition, Tool \\
comparison
\end{tabular} & Vc Increases tool wear also increases \\
\hline
\end{tabular}




\begin{tabular}{|c|c|c|c|c|}
\hline $\begin{array}{l}\text { Rastee et al. } \\
\text { (2014) [53] }\end{array}$ & $\begin{array}{l}\text { Material: Standard DSS EN1.4462 } \\
\text { and Super DSS EN } 1.4410 \\
\text { Tools: carbide inserts (CNMG } \\
\text { 120408-MM 2025) }\end{array}$ & $\begin{array}{l}\text { Input- Vc }(100,180 \mathrm{~m} / \mathrm{min}), \mathrm{fz}(0.15,0.2 \\
0.25,0.3,0.35,0.4 \mathrm{~mm} / \mathrm{rev}), \text { ap }(1 \mathrm{~mm}) \\
\text { Dry and Wet cutting condition, } \\
\text { Output - Tool wear }\end{array}$ & MOBA, ANOVA & $\begin{array}{l}\text { At low } \mathrm{Vc} \text { is the most dominant parameter for tool } \\
\text { wear }\end{array}$ \\
\hline $\begin{array}{l}\text { Krolczyk } \\
\text { Grzegorz et al. } \\
(2015)[54]\end{array}$ & $\begin{array}{l}\text { Material: DSS- } 1.4462 \text { (DIN EN } \\
\text { 10088-1) } \\
\text { Tools: TiCN / Al2O3 / TiN about 5.5 } \\
\mu \mathrm{m} \text { thickness (T1) and TiN / Ti(C,N) } \\
\text { Ti(N,B) / TiN / Ti(C,N) / Ti(C,N) } \\
\text { about } 12 \mu \mathrm{m} \text { thickness (T2). }\end{array}$ & $\begin{array}{l}\text { Input- Vc(50 } 100150 \mathrm{~m} / \mathrm{min}), \mathrm{fz}(0.20 .3 \\
0.4 \mathrm{~mm} / \mathrm{rev}) \\
\text { Output - Tool wear }\end{array}$ & $\begin{array}{l}\text { ANOVA, TRDM, } \\
\text { Signal-to-noise Ratio }\end{array}$ & $\mathrm{Vc}$ and $\mathrm{f}_{\mathrm{z}}$ were affecting the life of the tool \\
\hline $\begin{array}{l}\text { Metelski Andrzej } \\
\text { et al. (2016) [55] }\end{array}$ & $\begin{array}{l}\text { Material: DSS } 1.4462 \text { (DIN EN } \\
\text { 10088-1), } \\
\text { Tools: Coated carbide inserts with } \\
\text { ISO code of TNMG 160408: GC 2025 } \\
\text { and CTC 1135 }\end{array}$ & $\begin{array}{l}\text { Input- Vc }(50,100,150 \mathrm{~m} / \mathrm{min}), \text { fz }\{0.2 \\
0.30 .4 \mathrm{~mm} / \mathrm{rev}) \\
\text { Output - Tool wear }\end{array}$ & $\begin{array}{l}\text { ANOVA, Dijkstra's } \\
\text { algorithm }\end{array}$ & Vc and $f_{z}$ were affecting the tool life \\
\hline $\begin{array}{l}\text { Diniz et al. } \\
\text { (2016) [56] }\end{array}$ & $\begin{array}{l}\text { Material: S41000 martensitic and } \\
\text { S41426, super martensitic stainless } \\
\text { steels } \\
\text { Tools: Coated cemented carbide tools }\end{array}$ & $\begin{array}{l}\text { Input- Tool material, the cutting } \\
\text { conditions, and the cooling/lubrication } \\
\text { system } \\
\text { Output - Tool wear }\end{array}$ & $\begin{array}{l}\text { SEM analysis with } \\
\text { EDS device }\end{array}$ & $\begin{array}{l}\text { Depth of cut is the most important parameter that } \\
\text { affect the life of the tool }\end{array}$ \\
\hline $\begin{array}{l}\text { Rajaguru and } \\
\text { Arunachalam } \\
(2017)[57]\end{array}$ & $\begin{array}{l}\text { Material: SDSS - S32750 } \\
\text { Tools: Tungsten carbide cutting insert } \\
\text { with geometry of TNMG } 160408\end{array}$ & $\begin{array}{l}\text { Input- Variable speed from } 150-5600 \mathrm{rpm} \\
\text { with the power rating of } 10 \mathrm{~kW}, \mathrm{Vc}(120 \\
\mathrm{m} / \mathrm{min}), \text { feed }(0.3 \mathrm{~mm} / \mathrm{rev}) \text { depth of cut } \\
(1 \mathrm{~mm}) \\
\text { Output - Tool wear, cutting force and } \\
\text { surface integrity }\end{array}$ & $\begin{array}{l}\text { SEM, EDS, X-ray } \\
\text { diffraction (XRD) } \\
\text { technique }\end{array}$ & $\begin{array}{l}\text { The tool wear [MT-TiCN]- Al2O3 coated tool } \\
\text { provided good wear resistance }\end{array}$ \\
\hline $\begin{array}{l}\text { De Paiva et al. } \\
\text { (2017) [58] }\end{array}$ & $\begin{array}{l}\text { Material: Super DSS (UNS32750) } \\
\text { Tools: chemical vapor deposited } \\
\text { (CVD) TiCN + Al2O3as well as } \\
\text { physical vapor deposited (PVD) TiCN } \\
\text { and AlTiN coatings }\end{array}$ & $\begin{array}{l}\text { Input- Back rake angle, clearance angle, } \\
\text { cutting edge angle, rake angle, side cutting } \\
\text { edge angle, and nose radius. } \\
\text { Output - Tool wear }\end{array}$ & XPS analysis & AlTiN-coated tool have the longest tool life \\
\hline $\begin{array}{l}\text { Ahmed et al. } \\
\text { (2017) [59] }\end{array}$ & $\begin{array}{l}\text { Material: Super DSS — Grade UNS } \\
\text { S32750 } \\
\text { Tools: Cemented carbide inserts } \\
\text { coated with PVD AlTiN and CVD } \\
\text { TiCN + A12O3 }\end{array}$ & $\begin{array}{l}\text { Input- Back rake angle, clearance angle, } \\
\text { wedge edge radius angle, and nose radius. } \\
\text { Output - Tool wear, Chip characteristics }\end{array}$ & $\begin{array}{l}\text { (SEM) equipped with } \\
\text { energy EDS, X-ray } \\
\text { Photoelectron } \\
\text { Spectroscopy (XPS). }\end{array}$ & $\begin{array}{l}\text { Tool life is the twice that of the CVD TiCN + } \\
\mathrm{A} 12 \mathrm{O} 3 \text { coated insert }\end{array}$ \\
\hline $\begin{array}{l}\text { Nomani et al. } \\
\text { (2017) [60] }\end{array}$ & $\begin{array}{l}\text { Material: Duplex SAF } 2205 \\
\text { Tools: WNMG-TF solid carbide } \\
\text { inserts }\end{array}$ & $\begin{array}{l}\text { Input- Vc }(94 \mathrm{~m} / \mathrm{min}), \mathrm{fz}(0.15 \mathrm{~mm} / \mathrm{rev}) \text {, } \\
\text { Output - Tool wear }\end{array}$ & $\begin{array}{l}\text { SEM and electron } \\
\text { backscatter diffraction } \\
\text { (EBSD) }\end{array}$ & Tool wear is dominated by built-up edge \\
\hline $\begin{array}{l}\text { Ahmed and } \\
\text { Veldhuis (2017) } \\
\text { [61] }\end{array}$ & $\begin{array}{l}\text { Material: Super DSS - S32750 } \\
\text { Tools: PVD deposited TiAlN coating } \\
\text { on a carbide insert }\end{array}$ & $\begin{array}{l}\text { Input- Point angle of } 80^{\circ} \text {, negative } \\
\text { geometry, nose radius of } 0.8 \mathrm{~mm} \\
\text { Output - Tool wear, Tribological } \\
\text { performance, Chip microstructure }\end{array}$ & $\begin{array}{l}\text { (SEM) with energy } \\
\text { dispersive spectroscopy } \\
\text { (EDS) }\end{array}$ & AlTiN insert Longest tool life \\
\hline $\begin{array}{l}\text { Nagy et al.(2019) } \\
{[62]}\end{array}$ & $\begin{array}{l}\text { Material: G X2CrNiMoCuN 26-6-3-3 } \\
\text { casted super duplex steel } \\
\text { Tools: Coated with TiAlN and other } \\
\text { with TiAlSiN }\end{array}$ & $\begin{array}{l}\text { Input- Vc }(70 \mathrm{~m} / \mathrm{min}) \text { and feed }(\mathrm{f}= \\
0.15 \mathrm{~mm}) \text {, } \\
\text { Output - Tool wear-burr and built-up edge } \\
\text { formation }\end{array}$ & $\begin{array}{l}\text { Stereo microscope } \\
\text { image analysis }\end{array}$ & $\mathrm{Vc}$ is the dominant parameter that effects the tool. \\
\hline Dyl (2019) [63] & $\begin{array}{l}\text { Material: Duplex cast stainless steel } \\
\text { type GX2CrNiMoCuN25-6-3-3 } \\
\text { Tools: } 2025 \text { grade - CCMT 09T308- } \\
\text { MM , } \\
\text { CCMT 09T308-UM , CCMT 09T304- } \\
\text { UM }\end{array}$ & $\begin{array}{l}\text { Input- Vc }(70 \mathrm{~m} / \mathrm{min}) \text {, fz }(0.2 \mathrm{~mm} / \mathrm{rev}) \text {, ap } \\
(0.5 \mathrm{~mm}) \text {, Nose Radius, Flank Angle, Rake } \\
\text { Angle } \\
\text { Output - Surface roughness, flank wear } \\
(\mathrm{VB}, \mathrm{mm}) \text { and crater wear }(\mathrm{KB}, \mathrm{mm})\end{array}$ & $\begin{array}{l}\text { Arithmetical mean } \\
\text { deviation and the } \\
\text { maximum height of } \\
\text { profile }\end{array}$ & $\begin{array}{l}\text { At lowest tool wear occurred at } \mathrm{f}_{\mathrm{z}}-0.1 \mathrm{~mm} / \mathrm{rev}, \mathrm{Vc} \\
70 \mathrm{~m} / \mathrm{min} \text {, depth of cut }-0.5 \mathrm{~mm}\end{array}$ \\
\hline $\begin{array}{l}\text { Narayanan and } \\
\text { Jagadeesha } \\
\text { (2020) [64] }\end{array}$ & $\begin{array}{l}\text { Material: Super DSS }-2507 \\
\text { Tools: PVD-coated tungsten carbide } \\
\text { inserts (CNMG 120408MT12) }\end{array}$ & $\begin{array}{l}\text { Input- Vc }(113 \mathrm{~m} / \mathrm{min}), \mathrm{fz}(0.35,0.26,0.21 \\
\mathrm{mm} / \mathrm{rev}) \text {, ap }(1.2,1.6,2.0 \mathrm{~mm}) \\
\text { Output - Cutting Temperature, Tool Wear }\end{array}$ & SEM analysis & $\begin{array}{l}\text { The coolant reduces the amount of flank wear up } \\
\text { to } 77.19 \text { percentage as compared to dry machining }\end{array}$ \\
\hline $\begin{array}{l}\text { Nomani et al. } \\
(2015)[68]\end{array}$ & $\begin{array}{l}\text { Material: Wrought duplex stainless } \\
\text { steel alloys SAF } 2205 \text { and SAF } 2507 . \\
\text { Tools: TiAIN+ TiN coated solid } \\
\text { carbide twist drill }\end{array}$ & $\begin{array}{l}\text { Input- Vc }(60 \mathrm{~m} / \mathrm{min}), \text { fz }(0.15 \mathrm{~mm} / \mathrm{rev}) \\
\text { ap }(30 \mathrm{~mm}) \\
\text { Output - Tool wear, Machinability }\end{array}$ & $\begin{array}{l}\text { SEM and optical } \\
\text { microscopic analysis }\end{array}$ & $\begin{array}{l}\text { SAF } 2205 \text { holds the better machinability in terms } \\
\text { of tool wear }\end{array}$ \\
\hline $\begin{array}{l}\text { Sonawane et al. } \\
(2020)[69] .\end{array}$ & $\begin{array}{l}\text { Material: DSS } 2205 \\
\text { Tools: AlTiN and AlTiCrN on } \\
\text { cemented carbide }\end{array}$ & $\begin{array}{l}\text { Input- Vc }(100 \text { to } 180 \mathrm{~m} / \mathrm{min}), \text { fz }(0.12 \text { to } \\
0.18 \mathrm{~mm} / \mathrm{rev}), \text {, ap }-0.8 \mathrm{~mm} \text { constant } \\
\text { Output - Nose wear, tool life and surface } \\
\text { roughness }\end{array}$ & BUE formation method & $\begin{array}{l}\text { For maximum tool life an machinability - the } \\
\text { parameter should be maintained at low cutting } \\
\text { speed and feed rate }\end{array}$ \\
\hline $\begin{array}{l}\text { Dinesh et } \\
\text { al.(2016) [71] }\end{array}$ & $\begin{array}{l}\text { Material: Duplex alloy steel } \\
\text { Tools: Cemented carbide tool }\end{array}$ & $\begin{array}{l}\text { Input- Vc, fz, ap and tool nose radii } \\
\text { Output - MRR and Surface roughness }\end{array}$ & & $\begin{array}{l}\mathrm{Vc}, \mathrm{f}_{\mathrm{z}} \text { is the most influential parameter for surface } \\
\text { roughness and MRR }\end{array}$ \\
\hline $\begin{array}{l}\text { Schultheiss et al. } \\
\text { (2019) [72] }\end{array}$ & $\begin{array}{l}\text { Material: DSS- LDX 2101, SAF } \\
\text { 2205, SAF } 2507 \\
\text { Tools: Ti(C,N) and Al2O3-coated } \\
\text { cemented carbide CNMG120412 } \\
\text { cutting tools. }\end{array}$ & $\begin{array}{l}\text { Input- } \mathrm{Vc}(125 \mathrm{~m} / \mathrm{min}), \mathrm{fz}(0.06,0.10, \\
0.15,0.20 \mathrm{~mm} / \mathrm{rev}), \text { ap }(3 \mathrm{~mm}) \text { and tool } \\
\text { nose radii }(0.4,0.8,1.2,1.6 \mathrm{~mm}), \\
\text { Output - Minimum chip thickness }\end{array}$ & $\begin{array}{l}\text { Finite element } \\
\text { simulation }\end{array}$ & $\begin{array}{l}\text { Decreasing size of the tool nose radius leads to } \\
\text { increased minimum chip thickness }\end{array}$ \\
\hline
\end{tabular}

Meta-Heuristics optimization techniques: Multi objective bat algorithm (MOBA).

Hybrid Algorithms: Hybrid global best harmony search (hgHS) algorithm, Taguchi coupled Fuzzy Multi Attribute Decision Making (FMADM), Analytical Hierarchy process Technique for Order Preference by Similarity to Ideal Solution (AHP-TOPSIS), Taguchi-VIKOR coupled with Firefly Algorithm Neural Network System (FANNS).
Comparsion methods: Tool Comparison, dry and wet (cooling / lubricating conditions).

The literature review on surface roughness, tool wear, machinability, chip volume report, material removal rate is presented in Table 2, shows that there is a limited research is available in the field of conducting the experiment using duplex stainless steel. The traditional and nontraditional technique used for DSS optimization is shown in Table 4. It also shows that there are numerous algorithms that can be used to optimize DSS materials. 


\begin{tabular}{|c|c|c|c|}
\hline & \multirow{2}{*}{$\begin{array}{c}\text { Tradit } \\
\text { ional } \\
\text { optimi } \\
\text { zation } \\
\text { techni } \\
\text { ques }\end{array}$} & $\begin{array}{l}\text { Modelin } \\
\text { g and } \\
\text { Optimiz } \\
\text { ation }\end{array}$ & $\begin{array}{l}\text { 1. Statistical Regression Technique and ANOVA 7. Response Surface } \\
\text { Methodology, } \\
\text { 2. Fuzzy Set Theory Artificial Neural Networks, 8. Knowledge-Based Expert } \\
\text { Svstems. }\end{array}$ \\
\hline & & $\begin{array}{l}\text { Mathe } \\
\text { matical } \\
\text { Tanoti: }\end{array}$ & $\begin{array}{l}\text { 1. Dynamic Programming, } \begin{array}{l}\text { 4. Geometric Programming, } \\
\text { 2. Goal Programming, }\end{array} \\
\text { 5. Quadratic Programming, }\end{array}$ \\
\hline \multirow{2}{*}{$\begin{array}{l}\text { Optimi } \\
\text { zation } \\
\text { Metho } \\
\text { ds }\end{array}$} & \multirow[b]{2}{*}{$\begin{array}{l}\text { Nontra } \\
\text { ditiona } \\
1 \\
\text { optimiz } \\
\text { ation }\end{array}$} & $\begin{array}{l}\text { Meta- } \\
\text { Heuristi } \\
\text { cs } \\
\text { Ontimiz }\end{array}$ & $\begin{array}{l}\text { 1. Genetic Algorithms, } \\
\text { 2. Simulated Annealing, } \\
\text { 7. Artificialial Immune Algorithm, } \\
\text { 3. Tabu Search, 8. Shuffled Frog Leaping Algorithm, } \\
\text { 4. Particle Swarm Ontimization. } \quad \text { 9. Harmonv Search Algorithm. }\end{array}$ \\
\hline & & $\begin{array}{c}\text { Hybrid } \\
\text { Algorith } \\
\text { ms }\end{array}$ & $\begin{array}{l}\text { 1. Genetic Simulated annealing algorithm (GSA), } \\
\text { 2. Hybrid immune algorithm (artificial immune algorithm and hill climbing } \\
\text { local search algorithm), } \\
\text { 3. Memetic algorithm (GA is combined with the heavy local search), } \\
\text { 4. Hybrid approach (GA, SA, and Tabu search), } \\
\text { 5. Heuristic algorithms such as SA, GA and hybrid algorithm (hybrid-GASA), } \\
\text { 6. Novel hybrid ant colony optimization approach, } \\
\text { 7. Adaptive network based fuzzy inference system (ANFIS) with the genetic } \\
\text { learning algorithm, } \\
\text { 8. Hybrid Taguchi-genetic learning algorithm (HTGLA), } \\
\text { 9. Multi-objective optimization method based on adaptive simulated annealing }\end{array}$ \\
\hline
\end{tabular}

Fig. 5. The traditional and non - traditional technique used for optimization

Table 4. Optimization methods used in Turning of DSS

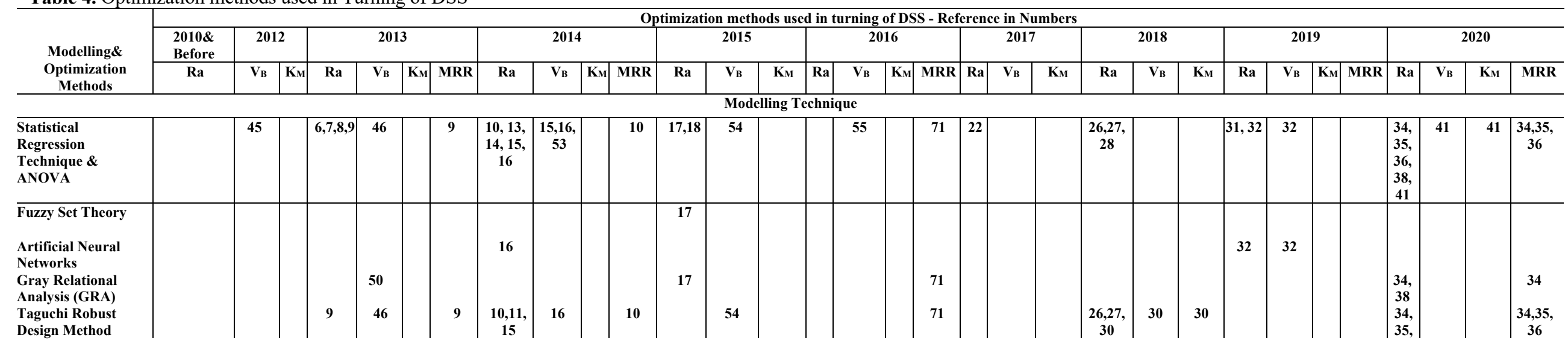


Mahesh Gopal and Endalkachew Mosisa Gutema/Journal of Engineering Science and Technology Review 14 (2) (2021) 119 - 135

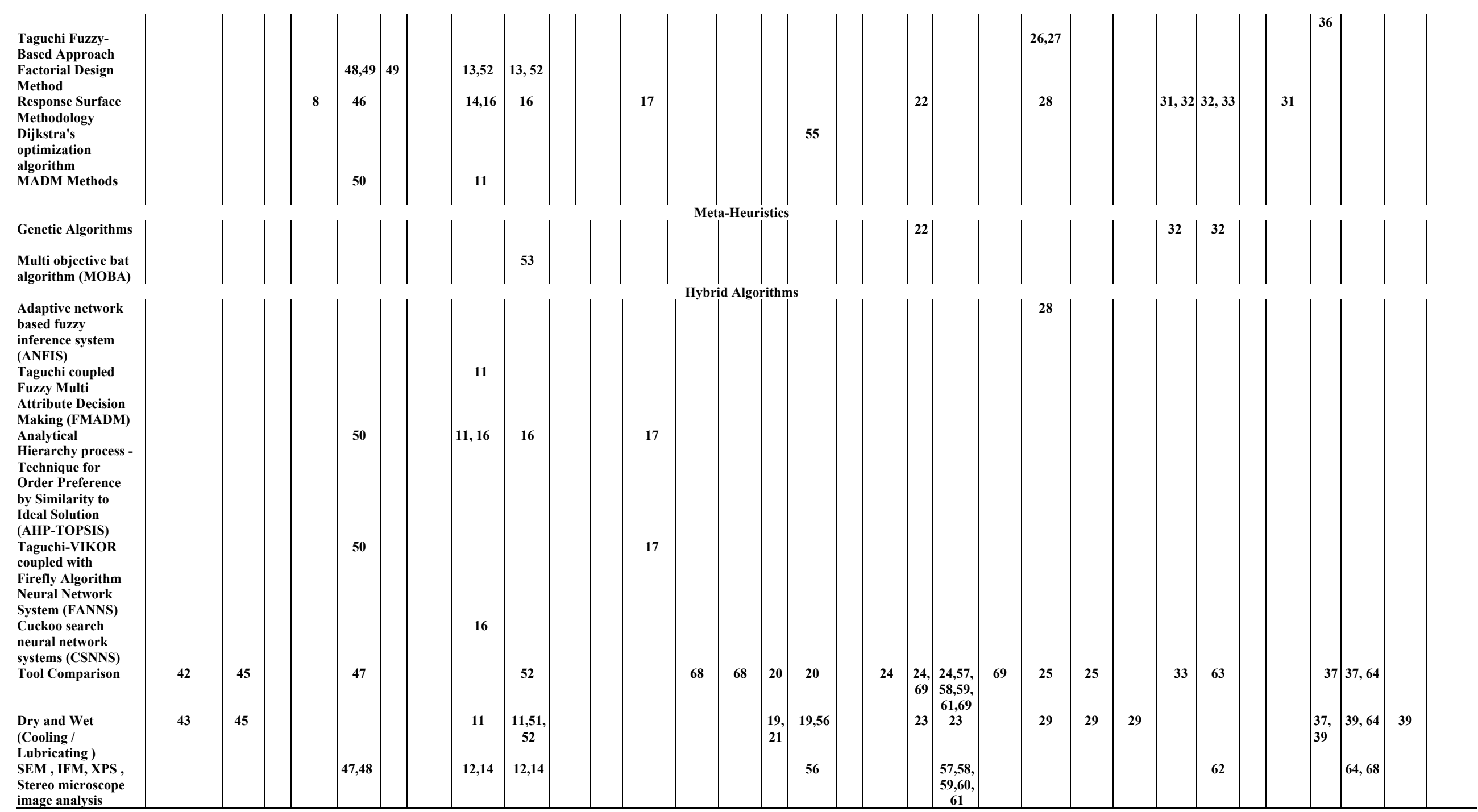




\section{Future Studies}

New duplex grades have been added to the market in recent years, with the primary aim of improving tolerance to reducing acids, pitting, and crevice corrosion.

However, the duplex is also far from achieving its maximum capacity.

The study, which started in 2010 and based on metal cutting utilizing the turning operation, indicates that there is a lack of analysis and literature in the DSS families.

Past studies have focused on 2205, 2507, and Zeron 100 products, with the primary goal of reducing surface roughness, tool wear, machinability, chip volume ratio, and material removal rate. As a result, there are many study opportunities in other duplex households.

With the aid of meta-heuristics and hybrid optimization methods, there are various study opportunities to maximize and forecast performance responses.

\section{Conclusion}

Because of their higher hardness, duplex steels are more complex to machine than traditional austenitic stainless steels. The application of DSS is high due to its physical and chemical properties. Nowadays the growth of machining process is glowing improved. The highly developed optimization that means computational techniques by using hybrid algorithms places a virtual role in the field of research. The computational techniques are very easy to optimize, precision accuracy, time saving, reliable and efficient way to solve any type of completed problems. The DSS have high strength, superior pitting corrosion resistance, work hardening, two times the tensile strength of other austenitic alloys, outstanding pitting and crevice corrosion. This review concludes that there is a reach possibilities in the field of turning of DSS and heuristic methods used for optimization. The elaborated research is required in the field of DSS families considering different parameters and cooling conditions. The Duplex grade is the alternative to austenitic grade for their excellent corrosion resistance. Today, the growth of new duplex stainless steel grades is tremendously energetic with a high possibility of success in several new markets.

This is an Open Access article distributed under the terms of the Creative Commons Attribution License.

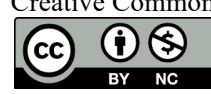

\section{References}

1. G.Chai,U.Kivisäkk, J.Tokaruk, Josefin Eidhagen, "Stainless Steel World", pp.27-33, 2007.

2. D.W. Jiang, GE.C. Sheng, X.J. Zhao, L. Junl, Ll. Shi, L.Shi, XS. Xue, "22Cr High-Mn-N Low-Ni Economical Duplex Stainless Steels", Journal of Iron and Steel Research, International, vol.19, pp. 50-56, 2012. 706X(12)60059-4

3. R.M.Davison, J.D. Redmond. "A guide to using duplex stainless steels", Materials and Design, vol.12, pp.187-192, 1992. DOI: https://doi.org/10.1016/0261-3069(91)90162-W

4. IMOA, "Practical guidelines for the fabrication of Duplex Stainless Steel", IMOA-International Molybdenum Association, Germany, 3rd edition, pp.6-7, 2014.

5. J. Charles, "Duplex stainless steels, a review after DSS'07 in Grado", Revue de Métallurgie-International Journal of Metallurgy, 105(3), pp.155-171, 2008 https://doi.org/10.1051/metal:2008028.

6. D. P. Selvaraj, C. Palanisamy, "Influence of cutting speed, feed rate and bulk texture on the surface finish of nitrogen alloyed duplex stainless steels during dry turning", Engineering, vol. 2, (06), pp.453, 2010. DOI : 10.4236/eng.2010.26059.

7. G. Krolczyk, S. Legutko, A. Stoić, "Influence of cutting parameters and conditions onto surface hardness of duplex stainless steel after turning process", Tehničkivjesnik, vol. 20, (06), pp.1077-1080, 2013. Paper ID: https://hrcak.srce.hr/112329.

8. G. Krolczyk, S. Legutko, M. Gajek, "Predicting the surface roughness in the dry machining of duplex stainless steel (DSS)", Metalurgija. vol. 52, (2), pp.259-262, $2013 . \quad$ Paper ID : https://hrcak.srce.hr/92683.

9. K. Kumar, J.S. Kumaar, A. Srinivasan, "Reducing surface roughness by optimizing the turning parameters", South African Journal of Industrial Engineering, vol.24, (2), pp.78-87, 2013. Paper ID : http://ref.scielo.org/52wjxp.

10. K.Kumar, J. S. kumaar, "Analysis and Optimization of Output Parameters using Taguchi Design Analysis", Recent Patents on Mechanical Engineering, vol. 7, (2), pp. 169-182, 2014. DOI: $10.2174 / 2212797607666140620003400$.

11. R. D. Koyee, R. Eisseler, S. Schmauder, "Application of Taguchi coupled Fuzzy Multi Attribute Decision Making (FMADM) for optimizing surface quality in turning austenitic and duplex stainless steels", Measurement, vol. 58, pp. 375-386, 2014. DOI: http://dx.doi.org/10.1016/j.measurement.2014.09.015.
12. D. O. Junior, C. Ancelmo, A. E. Diniz, R. Bertazzoli, "Correlating tool wear, surface roughness and corrosion resistance in the turning process of super duplex stainless steel", Journal of the Brazilian Society of Mechanical Sciences and Engineering, vol. 36, (4), pp. 775-785, 2014.DOI: https://doi.org/10.1007/s40430-013-0119-6.

13. G. M. Krolczyk, S. L. Legutko, "Experimental analysis by measurement of surface roughness variations in turning process of duplex stainless steel", Metrology and Measurement Systems. vol. 21 (4), pp.759-770, 2014. DOI: 10.2478/mms-2014-0060

14. M, Thiyagu, N. Arunkumar, "Experimental Studies in Machining Duplex Stainless Steel using Response Surface Methodology", International Journal of Mechanical and Mechatronics Engineering IJMME-IJENS, vol.14 (03), pp.48- 61, 2014. Paper ID: 1458034949-IJMME-IJENS.

15. D. P. Selvaraj, P. Chandramohan, M. Mohanraj, "Optimization of surface roughness, cutting force and tool wear of nitrogen alloyed duplex stainless steel in a dry turning process using Taguchi method", Measurement, vol. 49, pp. 205-215, 2014. DOI: : https://doi.org/10.1016/j.measurement.2013.11.037.

16. R. D. Koyee, U. Heisel, R. Eisseler, S. Schmauder, "Modeling and optimization of turning duplex stainless steels", Journal of Manufacturing Processes, vol. 16 (4), pp. 451-467, 2014. DOI: https://doi.org/10.1016/j.jmapro.2014.05.004 .

17. A.D. Rastee, "Modeling and optimization of turning duplex stainless steels", 2015. http://dx.doi.org/10.18419/opus-4601.

18. H. R. Gardi, K. A. Abdullah, H. K. Shakr, "Surface Roughness of Super Duplex Stainless Steel SAF 2507 During Turning", Journal of University of Duhok, Pure and Eng. Sciences, vol. 18, (1), pp. 47-53, pp. 2015.

19. G. M. Krolczyk, P. Nieslony, R. W. Maruda, S. Wojciechowski, "Dry cutting effect in turning of a duplex stainless steel as a key factor in clean production", Journal of Cleaner Production. 142, pp. 3343-3354, 2016.

https://doi.org/10.1016/j.jclepro.2016.10.136.

20. K. Rohit, S. Kadam, V. Chavan, M. Sadaiah, "Experimental Investigations on Surface Roughness, Cutting Forces and Tool Wear in the Turning of Super Duplex Stainless Steel with PVD Coated Carbide Inserts", In Proceedings of 6th International and 27th All India Manufacturing Technology, Design and Research Conference, pp. 16-18, 2016.

21. G.M. Krolczyk, R. W. Maruda, P. Nieslony, M. Wieczorowski, "Surface morphology analysis of duplex stainless steel (DSS) in 
clean production using the power spectral density", Measurement, $\begin{array}{llll}\text { vol. } & 94, & 464-470, & \text { DOI: }\end{array}$ https://doi.org/10.1016/j.measurement.2016.08.023.

22. V. Mario, S. Jozić, "Development and optimization of surface roughness predictive models in turning super duplex stainless steel by using artificial intelligence methods", Mechanical Technologies and Structural Materials , 2017 , pp. 149-158, 2017. CROSBI ID: 895952.

23. P.J. Liew, U. S. Hashim, M. N. A. Rahman, "Effect of Chilled Air Coolant on Surface Roughness and Tool Wear when Machining 2205 Duplex Stainless Steel", Journal of Advanced Manufacturing Technology, vol.11, (1), pp. 61-68, 2017.

24. S. Kadam, K. Rohit, M. Sadaiah, "Experimental Investigations on Surface Roughness, Cutting Forces and Tool Wear in Turning of Super Duplex Stainless Steel With Coated Carbide Inserts", In International Manufacturing Science and Engineering Conference, American Society of Mechanical Engineers, vol. 50732, p. V002T03A015. 2017.

25. J. R. Gamarra, A. E. Diniz, "Taper turning of super duplex stainless steel: tool life, tool wear and workpiece surface roughness", Journal of the Brazilian Society of Mechanical Sciences and Engineering, vol. 40, (1), pp. 1-13, 2018.. DOI: https://doi.org/10.1007/s40430018-0991-1.

26. K. Pawan, J. P. Misra, "A surface roughness predictive model for DSS longitudinal turning operation", DAAAM International Scientific Book, 285-296, 2018

10.2507/daaam.scibook.2018.25.

27. D .P. Selvaraj, "Optimization of surface roughness of duplex stainless steel in dry turning operation using Taguchi technique", Materials Physics and Mechanics, vol. 40, pp. 63-70, 2018. DOI: http://dx.doi.org/10.18720/MPM.4012018_8.

28. V. Mario, S. Jozić, D. Bajić, "Surface roughness modelling in super duplex stainless steel turning," International Journal for Engineering Modelling, vol. 31, (3), pp. 19-34, 2018. DOI: 10.31534/engmod.2018.3.ri.02f.

29. M, Dhananchezian, M. R. Priyan, G. Rajashekar, S. Narayana, "Study the effect of cryogenic cooling on machinability characteristics during turning duplex stainless steel 2205," Materials Today: Proceedings, vol. 5, (5), pp. 12062-12070, 2018. DOI: https://doi.org/10.1016/j.matpr.2018.02.181

30. D. A. Ghatge, R. Ramanujam, B. S. Reddy, M. Vignesh, "Improvement of machinability using eco-friendly cutting oil in turning duplex stainless steel", Materials Today: Proceedings 5, (5), pp. $12303-12310,2018$. https://doi.org/10.1016/j.matpr.2018.02.208.

31. V. Vijayan, B. Sureshkumar, G. Sathishkumar, R. Yokeshwaran, "Analysis of Machining Parameters in Turning Operation on Duplex 2205 by using RSM for Vehicle Structure", International Journal of Vehicle Structures \& Systems, vol. 11, (1), pp. 113-116, 2019.

DOI: 10.4273/ijvss.11.1.20.

32. N. Subhash, S. Soumya , P. N. Raj, T. Jagadeesha, "Experimental Study on Tool Wear and Optimization of Process Parameters Using ANN-GA in Turning of Super-Duplex Stainless Steel Under Dry and Wet Conditions", In Advances in Manufacturing Technology, pp. 411-420, 2019. DOI: https://doi.org/10.1007/978-981-13-6374$0 \_47$.

33. G. Sonawane, and V. Sargade, "Studies on the characterization and machinability of duplex stainless steel 2205 during dry turning", International Journal of Mechanical and Industrial Engineering, vol. 13(5), 349-353, 2019.

34. G. Dinde, G. S. Dhende, "Multi-response Optimization of Process Parameters During Wet Turning of Super Duplex Stainless Steel UNS S32760 Using Taguchi-Grey Relational Analysis", In Optimization Methods in Engineering, pp. 417-428. DOI: https://doi.org/10.1007/978-981-15-4550-4_25.

35. P. Kumar, J. P. Misra, "Optimization of duplex stainless steel dry turning parameters using desirability function", Materials Today: Proceedings, 2020. https://doi.org/10.1016/j.matpr.2020.02.324.

36. G. Dinde, G. S. Dhende, "Optimizing Parameters for Wet Turning of Super-Duplex Stainless Steel UNS S32760 Adopting Taguchi Methodology", In Optimization Methods in Engineering, 2020, pp. 403-415. DOI: https://doi.org/10.1007/978-981-15-4550-4_24

37. D. Narayanan, V. G. Salunkhe, V. Dhinakaran,T. Jagadeesha, "Experimental Evaluation of Cutting Process Parameters in Cryogenic Machining of Duplex Stainless Steel", In Advances in Industrial Automation and Smart Manufacturing, pp. 505-516, 2020 . 4739-3_44
38. A. Mavi, "Evaluation of Cutting Parameters by Determination of the Grey Correlation Analysis Methods of the Effects on the Cutting Force and Surface Roughness of Duplex Stainless Steels (2205)", Technical Gazette, vol. 27, (1), 270-275, 2020. DOI: https://doi.org/10.17559/TV-20181220075328.

39. J. Rajaguru, N. Arunachalam, "A comprehensive investigation on the effect of flood and MQL coolant on the machinability and stress corrosion cracking of super duplex stainless steel", Journal of Materials Processing Technology, vol. 276, pp. 116417, 2020. DOI: https://doi.org/10.1016/j.jmatprotec.2019.116417.

40. N. Subhash, T. Jagadeesha, M. Law, "Investigations on machinability and machining stability of turning super duplex stainless steel," International Journal of Machining and Machinability of Materials, vol. 22, (5), pp. 386-405, 2020. DOI: https://doi.org/10.1504/IJMMM.2020.109849

41. G. D. Sonawane, V. G. Sargade, "Machinability Study of Duplex Stainless Steel 2205 During Dry Turning", International Journal of Precision Engineering and Manufacturing, 2020, pp. 1-13. DOI: https://doi.org/10.1007/s12541-019-00305-8.

42. L. Jiang, H. Hänninen, J. Paro, V. Kauppinen, "Active wear and failure mechanisms of TiN-Coated high speed steel and tin-coated cemented carbide tools when machining powder metallurgically made stainless steels," Metallurgical and Materials Transactions, vol.27 A, (9), pp. 2796-2808, 1996. DOI: https://doi.org/10.1007/BF02652372

43. T. B. Bouchnak, G. Germain, P.Robert, and J. L. Lebrun, "High pressure water jet assisted machining of duplex steel: machinability and tool life," International Journal of Material Forming, vol. 3, (1). pp. 507-510, 2010. DOI: 10.1007/s12289-010-0818-9.

44. F. Schultheiss, J.E. Ståhl, "Machinability of duplex stainless steelsA study with focus on the tool wear behaviour," In Swedish Production Symposium, The Swedish Production Academy, pp. 271-277, 2011.

45. E. Ahmadi, R. M. Homami, S. Rahmati, "Experimental investigation and mathematical modeling of the composite ceramic cutting tools with alumina base in the machining process of $\mathrm{PH}$ hardened Austenitic-ferritic (Duplex) stainless steel", ADMT Journal , 5, (2), 2012 .

46. K.S. Kumar, and J. S. Senthilkumaar, "Analysis of flank wear and chip morphology when machining super duplex stainless steel in a gas cooled environment", International Journal of Engineering and Technology, vol.5, (6), 5045-5056, 2013.

47. K. Grzegorz, S. Legutko, and P. Raos, "Cutting wedge wear examination during turning of duplex stainless steel", TehničkiVjesnik-Technical Gazette, vol. 20, (3). vol. 413-418, 2013. doi: https://hrcak.srce.hr/104066.

48. K. Grzegorz, M. Gajek, S. Legutko, "Effect of the cutting parameters impact on tool life in duplex stainless steel turning process, "Tehničkivjesnik", vol. 20, (4), pp.587-592, 2013. DOI: https://hrcak.srce.hr/106684.

49. K. Grzegorz, M. Gajek, and S. Legutko, "Predicting the tool life in the dry machining of duplex stainless steel", Eksploatacja i Niezawodność, 15, pp. 62-65, 2013.

bwmeta1.element.baztech-article-BAT1-0043-0063

50. R.D. Koyee, S. Schmauder, R. Eisseler, "Machining of stainless steels: A comparative study", In 3rd International Conference on Advanced Manufacturing Engineering and Technologies, pp. 53$62,2013$.

51. K.S. Kumar, J. S. Senthilkumaar, R. Thirumalai, "Chip morphology investigation among dry, wet and gas cooled machining of super duplex stainless steel, " In Applied Mechanics and Materials, vol. $\begin{array}{llll}592, & \text { pp. } & 811-815, & 2014 .\end{array}$ 10.4028/www.scientific.net/AMM.592-594.811.

52. G.M. Krolczyk, P. Nieslony, and S. Legutko, "Determination of tool life and research wear during duplex stainless steel turning", Archives of Civil and Mechanical Engineering, vol. 15,(2), pp. 347354, 2015. DOI: http://dx.doi.org/10.1016/j.acme.2014.05.001.

53. K.D. Rastee, U. Heisel, S. Schmauder, and R. Eisseler, "Experimental investigation and multi-objective optimization of turning duplex stainless steels", International Journal of Manufacturing Engineering, pp.1-13, 2014. DOI: http://dx.doi.org/10.1155/2014/921081.

54. G. Krolczyk, M. Andrzej, M. Radoslaw and L. Stanislaw, "Taguchi Design of Experiment in the Optimization of Tool Life in Turning Process of Duplex Stainless Steel DSS", In Applied Mechanics and Materials, vol. 808, pp. 66-71, 2015.

10.4028/www.scientific.net/AMM.809-810.189.

55. A. Metelski, S. Krile , R.W. Maruda, S.Legutko, G. M. Krolczyk, "Dynamic programming approach in the optimization of tool life in 
turning process of duplex stainless steel DSS," In Key Engineering Materials, vol. 686, pp. 143-148, 2016.

10.4028/www.scientific.net/KEM.686.143.

DOI:

56. A.E. Diniz, Á. R. Machado, J. G. Corrêa, "Tool wear mechanisms in the machining of steels and stainless steels", The International 3168, 2016. DOI: 10.1007/s00170-016-8704-3.

57. J. Rajaguru, N. Arunachalam, "Coated tool performance in dry turning of super duplex stainless steel", Procedia manufacturing, vol. 10, pp. 601-611, 2017. 10.1016/j.promfg.2017.07.061.

58. de P. M. F. José , R. D. Torres, F. L. Amorim, D. Covelli, M. Tauhiduzzaman, S. Veldhuis, G. Dosbaeva, G. F. Rabinovich, "Frictional and wear performance of hard coatings during machining of superduplex stainless steel", The International Journal of Advanced Manufacturing Technology, vol. 92, (1-4) pp. 423432, 2017. DOI: 10.1007/s00170-017-0141-4.

59. S. Ahmed, Yassmin, J. M. Paiva, D. Covelli, S. C. Veldhuis, "Investigation of coated cutting tool performance during machining of super duplex stainless steels through 3D wear evaluations", Coatings, vol. 7, (8), pp. 1-15, $2017 . \quad$ DOI: https://doi.org/10.3390/coatings 7080127.

60. J. Nomani, A. Pramanik, T. Hilditch, G. Littlefair, "Stagnation zone during the turning of Duplex SAF 2205 stainless steels alloy," Materials and Manufacturing Processes, vol. 32, (13), pp.14861489, 2017. DOI: https://doi.org/10.1080/10426914.2017.1279289.

61. Y. S. Ahmed, S. C. Veldhuis, "The study of wear performance and chip formation of coated carbide tools during machining super duplex stainless steels", In Proceedings of the 6th International Conference Virtual Machining Process Technology, Montreal, Canada, vol. 29. 2017.

62. A. I. Nagy, E. R. Fábián, R. Horváth, P. Terek, "Difficulties in the machining super Duplex stainless steels", Müszaki Tudományos Közlemények, vol. 11, (1), pp. 141-144, 2019. DOI: https://doi.org/10.33894/mtk-2019.11.31.

63. T. C. Dyl, "The effect of parameters and geometry cutting edge after turning of the duplex cast steel on the maximum tool flank wear", Journal of KONES, vol. 26, (2), pp. 29-35, 2019. doi: 10.2478/kones-2019-0029.

64. D. Narayanan, T. Jagadeesha, "Process Capability Improvement Using Internally Cooled Cutting Tool Insert in Cryogenic Machining of Super Duplex Stainless Steel 2507," In Innovative Product Design and Intelligent Manufacturing Systems, pp. 323330, 2020. DOI: https://doi.org/10.1007/978-981-15-2696-1_31. Journal of Advanced Manufacturing Technology, vol. 87, pp. 3157 -

65. Gunn, "Duplex Stainless Steels: Microstructure, Properties and Applications," Abington Publishing, Cambridge, England, pp. 204, 1997.

66. N. Renaudot, E. Chauveau, M. Mantel, "1.4669, a new lean duplex stainless steel with improved toughness and machinability", La Metallurgia, Italiana . 2012 .

67. G. Krolczyk, S. Legutko, "The machinability of duplex stainless steel-solutions in practice", Manufacturing technology, vol. 13, (4), pp. 473-478, 2013. 2489/MT/13/4/473.

68. J. Nomani, A . Pramanik, T. Hilditch, G. Littlefair, "Chip formation mechanism and machinability of wrought duplex stainless steel alloys," The International Journal of Advanced Manufacturing Technology, vol. 80, (5-8), pp. 1127-1135, $2015 . \quad$ DOI: 10.1007/s00170-015-7113-3.

69. G. D. Sonawane, V. G. Sargade, "Machinability studies of Duplex Stainless Steel 2205 using coated tools", Proc of 10 th Int conf on Precision, Meso, Micro and Nano Engineering, , pp. 460-463, 2017.

70. M. Patel, G. R. Chate, B. M. B. Parappagoudar, and K. Gupta, "Machining of Hard Materials: A Comprehensive Approach to Experimentation, Modeling and Optimization", Springer Nature, 2020.

71. S. Dinesh, A. G. Antony, S. Karuppusamy, B. S. Kumar, V. Vijayan, "Experimental investigation and optimization of machining parameters in CNC turning operation of duplex stainless steel," Asian Journal of Research in Social Sciences and Humanities, vol. 6, (10), pp.179-195, 2016. DOI: 10.5958/22497315.2016.01006.6.

72. F. Schultheiss, M. Agmell, V. Bushlya, J. E. Ståhl, "Analysis of the minimum chip thickness during turning of duplex stainless steel," Proceedings of the Institution of Mechanical Engineers, Part B: Journal of Engineering Manufacture, vol. 233, (7), pp. 1733-1744, 2019. DOI: $10.1177 / 0954405418790772$.

73. R. V. Rao, "Advanced Modelling and optimization of Manufacturing Processes", International Research and Development, Springer Series in Advanced Manufacturing, Springer London Dordrecht Heidelberg New York, 2011. DOI: 10.1007/978-0-85729-015-1.

74. Meriyem Chergui, Aziza Chakir, "IT Governance Knowledge: From Repositories to Artificial Intelligence Solutions", Journal of Engineering Science and Technology Review, 13 (5), 67 - 76, (2020). DOI:10.25103/jestr.131.10.

75. Bilal Tolbi, "Optimal Supervisory Control of Two Phases Intersection Using Hybrid-based Model Approach", Journal of Engineering Science and Technology Review, 13 (5), 106 - 113, 2020. DOI:10.25103/jestr.135.14.

\section{Nomenclature}

$\mathrm{v}_{\mathrm{c}} \quad$ Cutting speed in $\mathrm{mm} / \mathrm{min}$

$\mathrm{f}_{\mathrm{z}} \quad$ Feed per tooth in $\mathrm{mm} /$ tooth

$a_{p} \quad$ Depth of cut in $\mathrm{mm}$

$\mathrm{n} \quad$ Spindle speed in $\mathrm{r} / \mathrm{min}$

$\mathrm{r}_{\mathrm{n}} \quad$ Nose radius in $\mathrm{mm}$

$\mathrm{P} \quad$ Cutting power in $\mathrm{W}$

$\mathrm{Ra} \quad$ Machined surface roughness in $\mu \mathrm{m}$

$\mathrm{V}_{\mathrm{B}} \quad$ Tool Wear in $\mathrm{mm}$

$\mathrm{K}_{\mathrm{M}} \quad$ Machinability of a material

$\mathrm{F} \quad$ Cutting force in $\mathrm{N}$

MRR Material Removal Rate in $\mathrm{mm}^{3} / \mathrm{min}$

$\mathrm{R}_{\mathrm{S}} \quad$ Residual stress

$\mathrm{M}_{\mathrm{i}} \quad$ Machinability index

z Number of cutting teeth

SRT Statistical Regression Technique

ANOVA Analysis of Variance

BBD Box-Behnken Design

ANN Artificial Neural Network

GRA Gray Relational Analysis

TRDM Taguchi Robust Design Method

TFBA Taguchi Fuzzy-Based Approach
GTMA Graph theory and matrix approach

FDM Factorial Design Method

RSM Response Surface Methodology

DOA Dijkstra's Optimization Algorithm

MADM Multiple Attribute Decision Making (MADM) and Multiple Objective Decision Making (MODM)

GA Genetic Algorithm

MOBA Multi objective bat algorithm

ANFIS Adaptive network based fuzzy inference system

FMADM Taguchi coupled Fuzzy Multi Attribute Decision

Making

AHP-TOPSIS Analytical Hierarchy process - Technique

for Order Preference by Similarity to Ideal Solution

IFM Infinite Focus Measurement Machine

MSQCI Multi-Surface Quality Characteristics Index

FANNS Taguchi - VIKOR coupled with Firefly Algorithm

Neural Network System

CSNNS Cuckoo search Neural Network Systems

HiPiMS High Power Impulse Magnetron Sputtering

UA Utility Analysis

SEMI Scanning Electron Microscope Image 